\title{
INFLUENCING TO TACKLE POVERTY AND INJUSTICE
}

\section{Learning from the past, looking to the future}

Ruth Mayne, Chris Stalker, Andrew Wells-Dang and Rodrigo Barahona, with contributions by Thomas Dunmore Rodriguez and Sally Golding

There have been many development advances in recent decades to celebrate. But our world is also undergoing major transformations, and facing profound development challenges which include extreme inequality, climate breakdown, gender injustice and the curtailment of civic freedoms. Civil society has an influential role to play, as part of broader alliances, in determining to what extent, and how, our societies will address these challenges. This paper uses Oxfam as a case study to share learning about how influencing - one of the three strands of its work alongside long-term development and humanitarian material assistance - can contribute to the creation of fairer, more inclusive and sustainable societies in the turbulent times in which we live.

\section{Oxfam Discussion Papers}

Oxfam Discussion Papers are written to contribute to public debate and to invite feedback on development and humanitarian policy issues. They are 'work in progress' documents, and do not necessarily constitute final publications or reflect Oxfam policy positions. The views and recommendations expressed are those of the author and not necessarily those of Oxfam.

For more information, or to comment on this paper, email Ruth Mayne, rmayne1@oxfam.org.uk 


\section{CONTENTS}

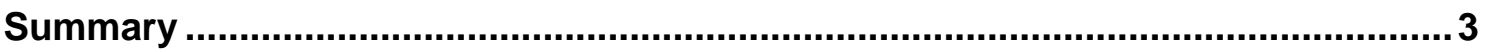

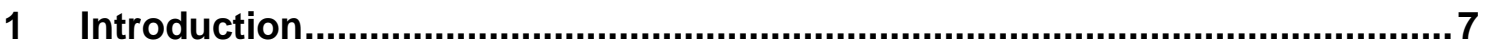

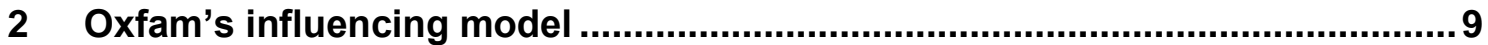

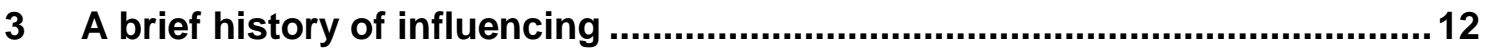

Oxfam's origins: World War II and the post-war period...................................................... 14

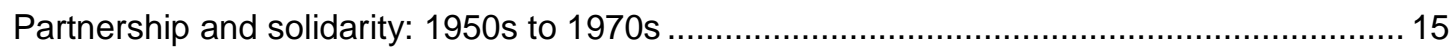

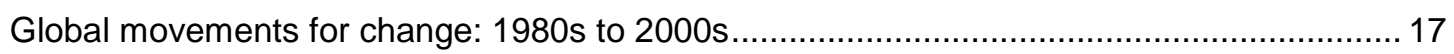

The worldwide influencing network: mid-2000s onwards ................................................. 21

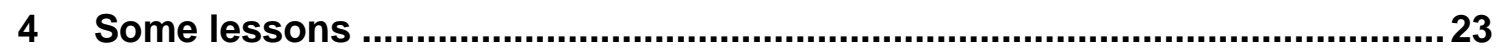

Partnerships and broad alliances are key to effective influencing ....................................... 23

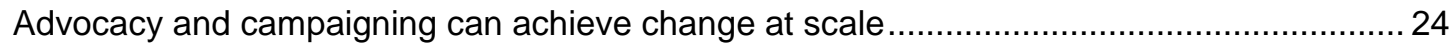

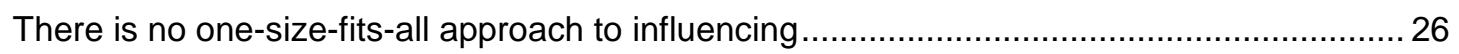

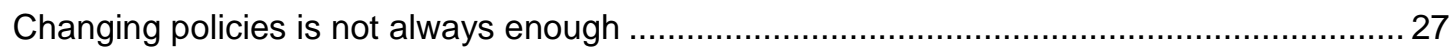

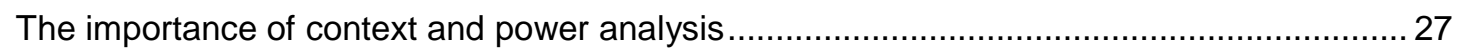

The mix, timing and sequencing of Influencing strategies and tactics matters ...................... 28

Social movements and local associations play important roles in poverty reduction ............. 30

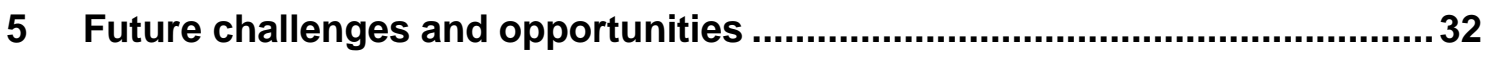

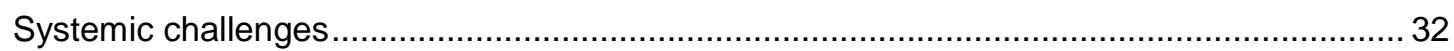

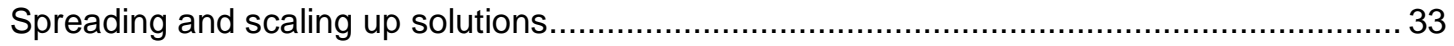

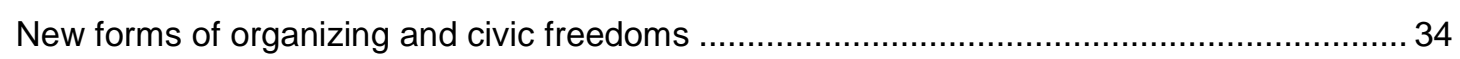

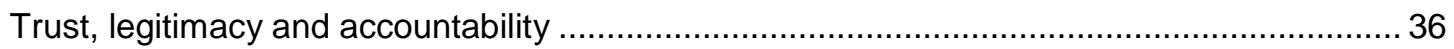

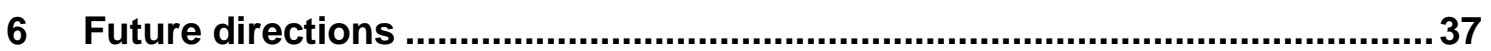

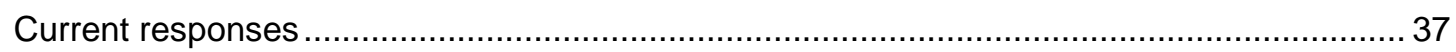

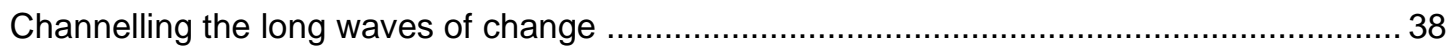

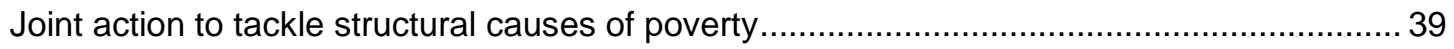

Broadening engagement and strengthening civil society voice ........................................ 39

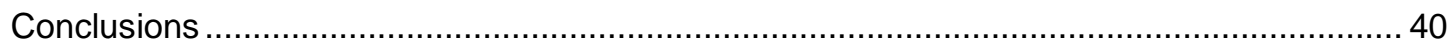

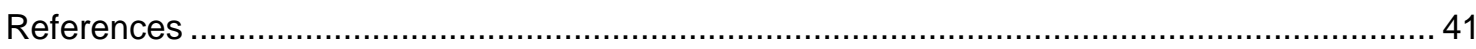

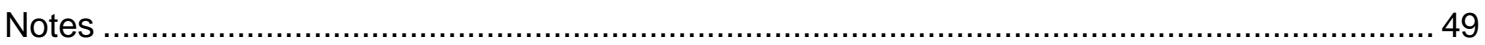


Recent decades have given humanity much to celebrate. Absolute poverty has fallen, and human development indicators have improved in many countries.

But our world is also undergoing major transformations: the urgent need to move to zero carbon economies; disruptive technologies such as artificial intelligence and robotics; the rise of the gig economy; mass migration and new refugee flows. These profound shifts are happening amid extreme inequality, climate breakdown, gender injustice and the curtailment of civic freedoms - which in turn exacerbate poverty or result from it, and constrain its reduction. Yet these transformations are also creating opportunities to tackle both old and new challenges. Civil society has an influential role to play, as part of broader alliances, in determining to what extent and how our societies will respond to these opportunities and challenges.

Using Oxfam as a case study, this paper shows how influencing - one of the three strands of Oxfam's work alongside long-term development and humanitarian material assistance - can be used to help tackle poverty, social injustice and attacks on civic freedoms.

\section{Influencing in Oxfam ${ }^{1}$}

Oxfam defines influencing as 'systematic efforts to change power relationships; attitudes, social norms and behaviours; the formulation and implementation of official policies, laws and regulations; budgets; and company policies and practices in ways that promote more just and sustainable societies without poverty'.

Influencing can be used in all contexts and thematic areas, and at all levels. It may stand alone or be integrated into programme and humanitarian work. Influencing strategies may include working with partners and allies to:

- Cultivate active citizenship and strengthen the capacity of marginalized groups and social movements to engage in decision making, have their voices heard and secure their rights;

- Influence and build the capacity of state institutions to engage poor and marginalized people to participate in decision making;

- Shift the terms of debate to open the space for policy change via communications, media networking and the use of influence;

- Advocate and campaign for changes to government and corporate decision making processes, policy and practice, in favour of poor and marginalized people, often involving for example:

- Lobby/dialogue (insider tactics): building relations with policy makers, gathering and presenting evidence about problems and solutions; dialogue and lobby;

- Public campaigning (outsider tactics): awareness raising' digital or other petitions; broadcast and social media; and public demonstrations;

- Support, spread and scale up innovative development solutions;

- Create strategic partnerships with, and convene, stakeholders to solve common problems, including creating safe spaces for dialogue between communities and government officials;

- Influence attitudes, social norms and behaviours, e.g. to help prevent violence against women and girls; improve health, hygiene and environmental behaviours; to address women's significant unpaid care burden; to help ensure the implementation of policies by officials; and motivate and enable people to action, including using framing and narratives, positive deviance and social learning processes, addressing structural influences etc.;

- Support the poverty reduction roles of social movements, women's rights and other civil society organizations (CSOs); 
- Build alliances and coalitions - including with civil society groups, state bodies, private companies, and non-conventional allies such as faith groups - to support any of the above strategies.

Influencing has been part of Oxfam's change model from its foundation in 1942. But, as Table 1 illustrates, its approach to influencing has evolved over time in response to changing contexts and learning from the people and organizations it works with.

Table 1: Key stages in the evolution of Oxfam's approach to influencing

\begin{tabular}{|c|c|c|c|c|}
\hline & $\begin{array}{l}\text { Humanitarian } \\
\text { response } \\
1942 \text { to } 1950 \text { s }\end{array}$ & $\begin{array}{l}\text { Partnership and } \\
\text { solidarity } \\
\text { 1950s to } 1970 \text { s }\end{array}$ & $\begin{array}{l}\text { Global movement } \\
\text { for change } \\
1980 \text { s to early } \\
2000 \text { s }\end{array}$ & $\begin{array}{l}\text { Worldwide multi- } \\
\text { level influencing } \\
\text { network } \\
\text { Mid-2000s } \\
\text { onwards }\end{array}$ \\
\hline $\begin{array}{l}\text { Main } \\
\text { emphasis of } \\
\text { change } \\
\text { model }\end{array}$ & $\begin{array}{l}\text { Alleviating } \\
\text { symptoms of } \\
\text { hunger }\end{array}$ & $\begin{array}{l}\text { Partnership in a } \\
\text { common movement } \\
\text { to address the root } \\
\text { causes of poverty } \\
\text { and hunger, as well } \\
\text { as its symptoms }\end{array}$ & $\begin{array}{l}\text { Addressing Northern }{ }^{2} \\
\text { and global causes of } \\
\text { poverty }\end{array}$ & $\begin{array}{l}\text { Addressing hidden, } \\
\text { invisible and visible } \\
\text { power; supporting } \\
\text { Southern-led national } \\
\text { change as part of a } \\
\text { world-wide } \\
\text { influencing network }\end{array}$ \\
\hline $\begin{array}{l}\text { Main } \\
\text { geographic } \\
\text { focus for } \\
\text { influencing }\end{array}$ & Western Europe & South and North & North and South & $\begin{array}{l}\text { South; less focus on } \\
\text { Northern and global } \\
\text { change }\end{array}$ \\
\hline $\begin{array}{l}\text { Main } \\
\text { influencing } \\
\text { issues }\end{array}$ & $\begin{array}{l}\text { Hunger } \\
\text { Refugees }\end{array}$ & $\begin{array}{l}\text { Human rights } \\
\text { Government aid and } \\
\text { foreign policies }\end{array}$ & $\begin{array}{l}\text { Aid } \\
\text { Debt and structural } \\
\text { adjustment } \\
\text { International trade and } \\
\text { investment rules and } \\
\text { corporate practices } \\
\text { Landmines and arms } \\
\text { trade treaty } \\
\text { Climate change }\end{array}$ & $\begin{array}{l}\text { Gender justice } \\
\text { Inequality } \\
\text { Climate change and } \\
\text { natural resources } \\
\text { Active citizenship and } \\
\text { sustainable peace } \\
\text { Civic space/rights }\end{array}$ \\
\hline $\begin{array}{l}\text { Main target } \\
\text { audiences }\end{array}$ & $\begin{array}{l}\text { Northern } \\
\text { governments } \\
\text { and publics }\end{array}$ & $\begin{array}{l}\text { Southern } \\
\text { governments via } \\
\text { partners } \\
\text { Northern } \\
\text { governments and } \\
\text { publics }\end{array}$ & $\begin{array}{l}\text { Global/multilateral } \\
\text { institutions } \\
\text { Northern governments } \\
\text { Southern governments } \\
\text { at the WTO } \\
\text { Publics and private } \\
\text { sector }\end{array}$ & $\begin{array}{l}\text { Southern } \\
\text { governments via } \\
\text { partners } \\
\text { Northern } \\
\text { governments, publics } \\
\text { and private sector } \\
\text { Regional and } \\
\text { multilateral } \\
\text { institutions }\end{array}$ \\
\hline $\begin{array}{l}\text { Focus of } \\
\text { influencing } \\
\text { strategies } \\
\text { (cumulative) }^{3}\end{array}$ & $\begin{array}{l}\text { Policy } \\
\text { influencing } \\
\text { Public } \\
\text { awareness- } \\
\text { raising in the } \\
\text { North }\end{array}$ & $\begin{array}{l}\text { Accompaniment and } \\
\text { support to Southern } \\
\text { CSOs and social } \\
\text { movements } \\
\text { Raising awareness } \\
\text { and mobilizing } \\
\text { solidarity in the } \\
\text { North }\end{array}$ & $\begin{array}{l}\text { Advocacy and } \\
\text { campaigning in North } \\
\text { and South } \\
\text { Strengthening civil } \\
\text { society voices in the } \\
\text { South and amplifying } \\
\text { their voices at a global } \\
\text { level }\end{array}$ & $\begin{array}{l}\text { Influencing social } \\
\text { norms, behaviours } \\
\text { and practices in the } \\
\text { South and North } \\
\text { Defending/widening } \\
\text { civic space and } \\
\text { freedoms } \\
\text { Improving state } \\
\text { governance }\end{array}$ \\
\hline
\end{tabular}




\begin{tabular}{|l|l|l|l|l|}
\hline $\begin{array}{l}\text { Oxfam role } \\
\text { and voice }\end{array}$ & $\begin{array}{l}\text { Prominent } \\
\text { Oxfam role and } \\
\text { voice in Western } \\
\text { Europe }\end{array}$ & $\begin{array}{l}\text { Supportive role to } \\
\text { CSOs in the South } \\
\text { Prominent Oxfam } \\
\text { role/voice in North }\end{array}$ & $\begin{array}{l}\text { Prominent Oxfam } \\
\text { voice/role in the North } \\
\text { and globally } \\
\text { Supportive role to } \\
\text { CSOs in South }\end{array}$ & $\begin{array}{l}\text { Supportive role to } \\
\text { CSOs in the South } \\
\text { Prominent Oxfam } \\
\text { voice/role on selected } \\
\text { issues where needed }\end{array}$ \\
\hline
\end{tabular}

Some of the lessons from Oxfam's history of influencing with partners and allies include:

- Partnerships and broad alliances, which depend on the quality of relationships, are essential.

- Civil society advocacy and public campaigning can successfully contribute to changing government and corporate policy and practice and create change at scale.

- There is no one-size-fits-all approach to influencing; advocacy and campaigning are not appropriate to all contexts - however, influencing (a broader concept) is.

- Changing government policies does not necessarily translate into practical benefits for people on the ground - complementary strategies may also be needed to address hidden and invisible forms of power and ensure that policies are actually implemented.

- If influencing strategies are to successfully address the structural causes of poverty, they need to be informed by thorough and regular context and power analyses and respond agilely to wider system change.

- Getting the right mix, timing and sequencing of influencing strategies and tactics is vital to effective influencing. For example, expanding the political space for civil society to exert influence on policy topics can help change policy but does not necessarily do so without complementary influencing strategies.

- Social movements and informal organizations can play crucial roles in helping people claim their rights or reduce poverty, but donor-driven, short-term, results-based cultures can constrain I/NGOs from supporting them.

\section{FUTURE DIRECTIONS}

INGOs themselves are facing a series of challenges that have been described as an existential threat. Externally these include shifting global power relations, the fragmentation of civil society groups around myriad single issues and changing funding landscapes. Internally their integrity as change agents is challenged by institutional demands such as growth, funders' priorities, brand visibility, and reporting. They are also criticised for being cumbersome, slow, and - like most large institutions - unable to 'white-water raft' through turbulent times. There are currently three main proposals for how INGOs might respond to such challenges:

- Stay big and grow as the only way to remain relevant, and provide a counterbalance to the powerful vested interests of market concentration by big business, and to global elites;

- Become more agile by downsizing, going local and supporting spin-off in order to support partners and develop, test and spread local solutions;

- Act as a hub to facilitate global networks that build power from below and link local, national, regional and global efforts as part of a global movement for change - an approach currently being pursued by much of the Oxfam confederation.

Size, agility and networks all matter greatly to organizations' futures. But care is also needed not to inadvertently jettison INGOs' established strengths. For example, Oxfam's history of tackling the structural causes of poverty has generated a set of influencing competences that are as important as ever. These include: its global reach and relationships; its ability to catalyze international solidarity; its holistic multi-level and multi-pronged influencing capacities and strategies; and its ability to make visible the human impacts of macro policies, among others. 
Such competences remain essential, but the rise of chauvinism and authoritarian populism also highlights the urgent need for new approaches and strategies. INGOs could help build a powerful constituency for change in both the South and North, while still being consistent with their missions, if they could:

- Coalesce around a positive shared vision and narrative aimed at creating a fairer, more inclusive and sustainable world. This will require much closer and longer term collaboration with and between both domestic and international movements and with development, human rights, labour, single issue, identity and environment groups, than has been seen so far.

- Jointly prioritize and assign a proportion of institutional resources to collectively address with allies the key structural causes of current system challenges - such as power and gender imbalances, corporate (lack of) regulation, or the capture of governments by elites. This will require greater use of multi-level, multi-pronged influencing strategies to tackle visible, invisible and hidden power;

- Broaden communications and public engagement strategies to engage a much wider section of society, rather than mainly focussing on existing active supporters. This would mean complementing the traditional focus on the poorest and most vulnerable, with strategies that address the anxieties and wants of wider sections of society affected by precarious employment, stagnant wages, the withdrawal of essential services and environmental destruction, South and North;

- Balance critiques with increased effort and investment to identify, model, promote and communicate solutions that can benefit wider sections of society. I/NGOs will need to stand ready to hook solutions to windows of opportunities as they emerge;

- Increase efforts to cultivate long-term active citizenship and organizations in the North as well as the South, rather than simply mobilizing people to support pre-defined branded campaigns. Doing so effectively will need a combination of new creative online and offline (face-to-face) participatory methods and support for training and mentoring;

- Increase understanding of, and support for, grass roots associations, women's rights organizations and social movements (while taking care not to impose agendas or inadvertently co-opt them);

- Spend more time directly and actively listening to, learning from and finding common ground and shared solutions with a more diverse range of individuals and organizations;

- Continue to strengthen the legitimacy, accountability and the internal cultures and practices of NGOs and CSOs, as important goals in their own right, and also to ensure the social mandate to operate.

The stakes could not be higher. If I/NGOs can learn from past success and failure to strengthen their influencing strategies, they can help to channel the current wave of public disenchantment towards humane, just and sustainable solutions; if they don't, others will inevitably do so in more regressive and chauvinist directions. 
There have been many development advances to celebrate in recent decades. But our world is also undergoing major transformations: the urgent need to move to zero carbon economies; disruptive technologies such as artificial intelligence and robotics; the rise of a gig economy; mass migration and new refugee flows. These profound shifts are happening in the context of extreme inequality, climate breakdown, gender injustice and the curtailment of civic freedoms in many countries.

But these transformations are also opening up new influencing opportunities. Civil society has an influential role to play, as part of broader alliances, in determining to what extent and how our societies will address these opportunities and challenges. Using Oxfam as a case study, this paper shows how influencing - one of the three strands of Oxfam's work alongside long-term development and humanitarian material assistance - can be used to help tackle the structural causes of poverty and to scale up solutions.

Historically, international NGOs (INGOs ${ }^{4}$ ) such as Oxfam and their partners have used a number of strategies in their efforts to eradicate poverty and social injustice, including:

- emergency humanitarian assistance;

- material support for long-term development programmes;

- advocacy and campaigning to tackle the structural causes of poverty; and

- cross-cutting efforts to strengthen civil society voice and capacity.

Much of the reputation and legitimacy of INGOs rests on their grassroots development and humanitarian programmes. However, advocacy and campaigning have become an increasingly important element in the work of some INGOs in recent years. Although less predictable and measurable than direct material assistance, they can lead to exponential results when successful (Schlangen and Coe, 2014).

In 2013, Oxfam began to use 'influencing' as an umbrella term to encapsulate the wide range of strategies and tactics that staff, partners and allies use to tackle the structural causes of poverty and to scale-up development solutions (Oxfam, 2013). The term includes, but also goes beyond, advocacy and campaigning as traditionally understood in Oxfam (See Box 1). For Oxfam, influencing is relevant to all issues, contexts and levels. It can be integrated into programme and humanitarian work or may take the form of specific campaigns. It usually involves working with partners, allies and coalitions.

\section{Box 1: Definitions}

Influencing: 'systematic efforts to change power relationships, attitudes, social norms and behaviours, and the formulation and implementation of official policies, laws and regulations, budgets, and company policies and practices in ways that promote more just and sustainable societies without poverty'. (Oxfam, 2013).

Advocacy and campaigning: systematic efforts to influence the policies and practices of government and corporate decision making processes, policy and practice in favour of poor and marginalized groups.

Other organizations use the terms 'advocacy' or 'campaigning' - instead of influencing - as broad umbrella terms meaning any organized action to achieve a desired change in policy, practice, norms, behaviours, etc. The adoption of the term 'influencing' in Oxfam reflects the particularities of its own history and decision making process. This paper does not suggest that other organizations should necessarily use the term 'influencing' in this way. 
Using Oxfam as a case study, this paper considers:

- how and why Oxfam's influencing strategies have changed over time;

- what lessons have been learned; and

- what influencing opportunities, challenges and possible directions there are for Oxfam and other INGOs in future.

INGOs working with their partners and allies to end poverty and injustice form one prominent but small part of wider national and global social justice movements. Nonetheless, we hope that the focus on the influencing approach and strategies of a single INGO, with partners and allies, will help contribute to discussion and learning about how to achieve change and the possible future roles and directions of INGOs.

This paper also aims to contribute to a greater internal understanding about what influencing entails in the varied contexts where Oxfam works. A 2017 internal staff survey showed that while ' $67 \%$ of staff said they understood what is meant by influencing for Oxfam ... it would appear they don't all understand the same thing'. This paper also hopes to clarify some of the questions about influencing within Oxfam, including for example about why the concept of influencing has become a priority, what it is and if and how it differs from previous Oxfam or other NGO change strategies. It also discusses some of the questions INGOs are facing about their roles and legitimacy.

It is not possible to do full justice to the incredibly rich range and diversity of influencing work and learning by Oxfam partner, allies and staff over time and across different countries, regions, levels and organizational affiliates. For reasons of scope, the paper therefore focuses on influencing related to long-term development rather than humanitarian issues, even though the latter has also played a significant role in Oxfam's work with important and rich learning (see for example: Black, 1992; Cousins et al., 2015).

The views and recommendations expressed in this discussion paper represent those of the authors, not necessarily Oxfam, but they have been informed by:

- experience and learning of many staff and partners over the years;

- comments and input from many people across the Oxfam confederation and externally;

- a desk review, including a mix of research papers, evaluations, metareviews, case studies and internal learning workshops;

- 20 interviews with a mix of Oxfam staff (present and past), partners and allies;

- webinars, presentation and discussions with staff, conducted between September 2017 and January 2018; and

- the personal experiences of the authors.

Section 2 outlines Oxfam's current influencing model. Section 3 considers how and why its influencing strategy has evolved over time. Section 4 identifies some key learning points. Section 5 explores future opportunities, challenges and directions for INGOs. Section 6 concludes the paper by suggesting some possible future directions. 


\section{OXFAM'S INFLUENCING APPROACH}

Oxfam aspires to make a sustained and significant positive impact on global poverty, inequality and injustice. This aspiration is underpinned by a belief that poverty and injustice are neither acceptable nor inevitable, and that change is possible through collective action. It also rests on a belief in the agency of poor and marginalized people and their representative organizations, the duty of governments to promote and protect people's rights, and the responsibility of businesses to respect human rights.

At core, its influencing approach involves helping to build a worldwide movement for change that rebalances power in favour of poor and marginalized groups - particularly women - and addresses the structural causes of poverty (Hoeidrup, 2015; Green, 2008). To this end it supports and builds the organizational capacity of such groups, including transformative women's leadership. It also works with representative organizations to influence the policies and practices that affect their members' lives. This approach is underpinned by a commitment to gender equality and respect for diverse identities. The interaction between empowered citizens, accountable states and a responsible private sector is considered fundamental to human development.

In 2013, Oxfam introduced the term influencing to describe its work with partners and allies to tackle the structural causes of poverty and to scale up change (see Box 1). Specific strategies may include:

- Cultivating active citizenship and strengthening the capacity of marginalized people and social movements to engage in decision making, have their voices heard and secure their rights;

- Influencing and building the capacity of state institutions to engage poor and marginalized people in decision making;

- Shifting the terms of debate to open the space for policy change via communications, media networking and the use of influencing;

- Advocating and campaigning for changes to government and corporate decision-making processes, policy and practice in favour of poor and marginalized groups often involving e.g.:

- Lobby/dialogue (insider tactics): building relations with policy makers, gathering and presenting evidence about problems and solutions; dialogue and lobby;

- Public campaigning (outsider tactics): awareness raising; digital or other petitions; broadcast and social media; and public demonstrations;

- Supporting, sharing and scaling up innovative development solutions, including by informing wider influencing efforts;

- Creating strategic partnerships with, and convening of, stakeholders to solve common problems, including creating safe spaces for dialogue between communities and government officials;

- Influencing attitudes, social norms and behaviours to help prevent violence against women and girls; improve health, hygiene and environmental behaviours; to address women's significant unpaid care burden; help ensure the implementation of policies by officials; and motivate and enable people to take action, including using framing and narratives, positive deviance and social learning processes, addressing structural influences etc.;

- Supporting the poverty reduction roles of social movements, women's rights and other civil society organizations (CSOs);

- Alliance and coalition building - including with civil society groups, state bodies and private companies, establishment and non-conventional allies such as faith groups - to support any of the above. 
As well as encouraging the use of a wide range of influencing strategies, in recent years Oxfam has sought to increase and embed influencing more consistently into its long-term development and humanitarian work. Country programmes are expected to integrate influencing strategies into their long-term development and humanitarian programmes in a mutually reinforcing overarching strategy (known as the 'one programme approach') rather than implement them as separate streams, although the extent to which this happens varies (Sanchez and Lenton, 2018). Alongside the influencing strategies outlined above, a key programmatic role for country programmes is to identify, pioneer and test effective solutions to poverty and injustice, and then use influencing to spread and scale them up, rather than to deliver large scale services that should be provided by duty holders. One external interviewee for this paper suggested that 'Oxfam has huge power around the globe. It should negotiate with big donors and home country governments and tell them what communities need, not be a contractor'. In Ethiopia, for example, an initiative which helped farmers to adapt to climate change - by providing weather insurance for their crops, access to credit, support to create savings and environmental rehabilitation projects such as watershed restoration - has spread to reach 24,000 farmers (Oxfam, undated).

\section{Box 2: Integrated local programming and influencing for olive oil in the West Bank}

An olive oil project in the West Bank, supported by Oxfam, aims to improve the livelihoods of small-scale male and female farmers. It integrates influencing with material and practical support, including by:

- Promoting partnerships between oil producers and other stakeholders, leading to the establishment of an olive oil unit in the Ministry of Agriculture, which has become a strong partner and advocate for sector-wide development and policy change;

- Building trust and alignment among stakeholders through joint action planning and facilitated dialogue between farmers, exporters and Palestinian public authorities;

- Strengthening the collective organization and negotiating power of small-scale farmers and women at all levels, from local to national cooperatives;

- Access to loans and practical support to help promote products and develop market strategies.

Source: Maes, 2016.

As much change happens at local and national levels, Oxfam is also seeking to rebalance some of its effort and resources away from the centrally coordinated global influencing characteristic of its work in the 1990s and 2000s, to provide greater support to national level influencing in the global South. Alongside this, it is creating a 'Worldwide Influencing Network' (WIN), with greater Southern leadership, which links together Oxfam staff and partners at national, regional and global levels and enables more decentralized and agile decision making. There is still some way to go to rebalance power relations in practice: a recent internal review indicated the need for greater financial investment for Southern influencing roles, as well as advisory, peer-to-peer and mentoring support on issues including risk management, media, digital engagement, power analysis and research skills. Nonetheless, the Enough campaign, launched in 2016, is leading the way with its Southernled collective leadership team (with support from the Oxfam International secretariat) and its overarching change strategy combined with decentralized national level influencing (Oxfam, 2016a).

It is also seeking to address more consistently and effectively the hidden and invisible, as well as visible, forms of power that can reinforce power and gender imbalances and constrain policy implementation (Rao \& Kelleher 2005; Rowlands, 2016) - such as cultural beliefs, social norms and behaviours. ${ }^{5}$ The We Can campaign, launched in 2004 in more than 20 countries, used dialogue and champions to change the cultural beliefs underpinning violence against women and girls, signing up around four million local 'change makers' (Michaela, 2011; Green, 2016). The 31 countries involved in the Enough campaign, are building on this, by working with partners and allies to change the social norms that perpetuate violence against women and girls, and. (Oxfam, 2016a; 
Thekkudan, et al., 2016). Similarly, the WE-Care initiative, ${ }^{6}$ which covers more than 20 countries, aims to change attitudes, norms and behaviours at household and community levels, and to influence governments, donors and the private sector to address women's significant unpaid care burden (see Box 15). Water, sanitation and health programmes are also increasingly addressing cultural beliefs and influencing the behaviours of public officials and communities, in addition to providing public education and infrastructure.

\section{Box 3: WE-Care initiative in Uganda}

In Uganda the We-Care initiative is led by two women's rights organizations, UWONET and the Women and Rural Development Network (WORUDET). As in other countries, WE-Care seeks to raise awareness of the contribution of unpaid and domestic care work to family wellbeing and the heavy and unequal responsibility borne by women. The initiative aims to catalyze action at local, national and international levels to distribute care work more evenly. In Uganda WE-Care has:

- Conducted and shared research on the distribution of care work, including gathering evidence from more than 3,160 people;

- Organized knowledge building and gender forums with more than 2,000 women's rights advocates;

- Held meetings with more than 500 community members, district-based advocacy group members and cultural and religious leaders to build a movement of male role models;

- Developed a strategy, and undertaken advocacy with civil society, private sector and government actors to influence national government to develop policies, services and infrastructure to address heavy and unequal care work.

Some of the results include:

- Change agents and model families have reached more than 1,500 community members and leaders through awareness-raising and advocacy initiatives;

- Commitments by district-level leaders to rehabilitate defunct boreholes, install piped water, and improve facilities in healthcare centres;

- Pledges by cultural and religious leaders to address the heavy and unequal care work in their communities, with some young men subsequently becoming more involved in care tasks including the collection of water and firewood;

- The Uganda Bureau of Statistics has included two additional questions on unpaid care work in national health surveys, and revised its data collection methodologies;

- Recognition in the Marriage and Divorce Bill of the contribution of unpaid care work to family and community development.

Source Davies, (2017). Women's Economic Empowerment and Care (WE-Care) - Oxfam: Phase 11 Interim Report. Annual Report. Oxfam and Hewlett Foundation

In 2018, historic cases of sexual abuse by INGO staff, including Oxfam, were highlighted by the media in the wake of the Me Too movement. Existing effort within Oxfam to address power and gender imbalances - both within the organization and between Oxfam and organizations and people it works with - was intensified along with work to increase alignment between its values, culture and practice, and external influencing objectives. As part of these efforts, it created a tenpoint plan (Oxfam, 2018a) and is working to build a 'culture of zero tolerance' towards harassment, abuse or exploitation. These measures build on Oxfam's existing accountability and transparency measures, such as regular public reporting; feedback and complaints mechanisms; diversity and inclusion measures; and efforts to improve operational practice (Oxfam, 2016b). 


\section{A BRIEF HISTORY OF INFLUENCING}

There are a number of perspectives on the historical development of NGOs' change strategies.

One view suggests they evolved in clear stages from:

- humanitarian aid to alleviate the symptoms of hunger and suffering during the pre- and post-war period; to

- supporting long-term community development from the mid-1970s onwards; to

- influencing the wider institutional and policy context from the late $1980 \mathrm{~s}$; to

- facilitating people's movements for social change aimed at long-term structural change (Korten,1987; Clark, 1991; Green, 2016).

Others have noted an evolution among NGOs from a needs-based to a rights-based approach that supports marginalized and poor groups and emphasises the role of the state as duty bearer (Offenheiser \& Holcombe 2003; Girvan, 2007; Walker \& Christie, 2015; Foresti \& Ludi, 2017). Yet others suggest that NGOs have become more aligned to state- and donor-led approaches (e.g. the Millennium Development Goals), having moved away from their early bottom-up grassroots participatory approaches (Banks \& Hulme, 2012).

However, in practice, NGO change strategies have not necessarily developed sequentially or along a fixed trajectory. For example, some I/NGOs such as Oxfam combined policy influencing and humanitarian relief from their outset, while others have increased their sub-contracted service delivery role over time, in both cases reversing Korten's trajectory. Additionally, the distinction between different change strategies can often be blurred: collective capacity building, for example, could form part of a campaign, programme or humanitarian strategy.

\section{Box 4: Other Northern-based INGOs}

Other INGOs - such as CARE, Save the Children, WaterAid and ActionAid - use a similar mix of change strategies to Oxfam. However, Oxfam appears to be the only one that explicitly uses the term 'influencing' as an overarching term (rather than advocacy or campaigning) and that explicitly defines itself as a worldwide influencing network. If they use the term influencing at all, other INGOs are inclined to see it as one strand of 'advocacy' and 'campaigning', e.g. policy influencing.

Nonetheless, there are many similarities between Oxfam and its counterparts. CARE seeks to tackle the underlying causes of poverty and social injustice, with change strategies including advocacy, learning, knowledge management and accountability. ActionAid uses campaigns to address the structural causes and consequences of poverty based on the basic principle of 'working together'. WaterAid uses advocacy as an approach for connecting local to global solutions. Save the Children embeds advocacy and campaigning in their strategic as well as tactical approaches to ending poverty by strengthening the voices of those with whom they work, partnerships, innovation and achieving impact at scale.

Sources: Christie and Coe, 2014; web and desk review.

Oxfam's change model has evolved over time in response to changing contexts, learning from partners, allies and affiliates and internal and external debate. Table 1 provides a summary of some of the key stages of this development. The rest of this section provides more historical detail about why and how Oxfam's influencing strategies have changed. 
Table 1: Keys stages in the evolution of Oxfam's approach to influencing

\begin{tabular}{|c|c|c|c|c|}
\hline & $\begin{array}{l}\text { Humanitarian } \\
\text { response } \\
1942 \text { to } 1950 \text { s }\end{array}$ & $\begin{array}{l}\text { Partnership and } \\
\text { solidarity } \\
\text { 1950s to } 1970 \text { s }\end{array}$ & $\begin{array}{l}\text { Global } \\
\text { movement for } \\
\text { change } \\
1980 \text { s to early } \\
2000 \text { s }\end{array}$ & $\begin{array}{l}\text { Worldwide multi- } \\
\text { level influencing } \\
\text { network } \\
\text { Mid-2000s onwards }\end{array}$ \\
\hline $\begin{array}{l}\text { Main } \\
\text { emphasis of } \\
\text { change } \\
\text { model }\end{array}$ & $\begin{array}{l}\text { Alleviating } \\
\text { symptoms of } \\
\text { hunger }\end{array}$ & $\begin{array}{l}\text { Partnership in a } \\
\text { common } \\
\text { movement to } \\
\text { address the root } \\
\text { causes of poverty } \\
\text { and hunger, as well } \\
\text { as its symptoms }\end{array}$ & $\begin{array}{l}\text { Addressing } \\
\text { Northern } 7 \text { and } \\
\text { global causes of } \\
\text { poverty }\end{array}$ & $\begin{array}{l}\text { Addressing hidden, } \\
\text { invisible and visible } \\
\text { power } \\
\text { Supporting Southern- } \\
\text { led national change } \\
\text { as part of a world- } \\
\text { wide influencing } \\
\text { network }\end{array}$ \\
\hline $\begin{array}{l}\text { Main } \\
\text { geographic } \\
\text { focus for } \\
\text { influencing }\end{array}$ & $\begin{array}{l}\text { Western } \\
\text { Europe }\end{array}$ & South and North & North and South & $\begin{array}{l}\text { South, less focus on } \\
\text { Northern and global } \\
\text { change }\end{array}$ \\
\hline $\begin{array}{l}\text { Main } \\
\text { influencing } \\
\text { issues }\end{array}$ & $\begin{array}{l}\text { Hunger } \\
\text { Refugees }\end{array}$ & $\begin{array}{l}\text { Human rights } \\
\text { Government aid } \\
\text { and foreign policies }\end{array}$ & $\begin{array}{l}\text { Aid } \\
\text { Debt and } \\
\text { structural } \\
\text { adjustment } \\
\text { International trade } \\
\text { and investment } \\
\text { rules \& corporate } \\
\text { practices } \\
\text { Landmines and } \\
\text { arms trade treaty } \\
\text { Climate change }\end{array}$ & $\begin{array}{l}\text { Gender justice } \\
\text { Inequality } \\
\text { Climate change and } \\
\text { natural resources } \\
\text { Active citizenship and } \\
\text { sustainable peace } \\
\text { Civic space/rights }\end{array}$ \\
\hline $\begin{array}{l}\text { Main target } \\
\text { audiences }\end{array}$ & $\begin{array}{l}\text { Northern } \\
\text { governments } \\
\text { and publics }\end{array}$ & $\begin{array}{l}\text { Southern } \\
\text { governments via } \\
\text { partners } \\
\text { Northern } \\
\text { governments and } \\
\text { publics }\end{array}$ & $\begin{array}{l}\text { Global/multilateral } \\
\text { institutions } \\
\text { Northern } \\
\text { governments } \\
\text { Southern } \\
\text { governments at } \\
\text { the WTO } \\
\text { Publics and } \\
\text { private sector }\end{array}$ & $\begin{array}{l}\text { Southern } \\
\text { governments via } \\
\text { partners } \\
\text { Northern } \\
\text { governments, publics } \\
\text { and private sector } \\
\text { Regional and } \\
\text { multilateral } \\
\text { institutions }\end{array}$ \\
\hline $\begin{array}{l}\text { Focus of } \\
\text { influencing } \\
\text { strategies } \\
\text { (cumulative) }^{8}\end{array}$ & $\begin{array}{l}\text { Policy } \\
\text { influencing } \\
\text { Public } \\
\text { awareness- } \\
\text { raising in the } \\
\text { North }\end{array}$ & $\begin{array}{l}\text { Accompaniment } \\
\text { and support to } \\
\text { Southern CSOs } \\
\text { and social } \\
\text { movements } \\
\text { Raising awareness } \\
\text { and mobilizing } \\
\text { solidarity in the } \\
\text { North }\end{array}$ & $\begin{array}{l}\text { Advocacy and } \\
\text { campaigning in } \\
\text { North and South } \\
\text { Strengthening civil } \\
\text { society voices in } \\
\text { the South and } \\
\text { amplifying their } \\
\text { voices at global } \\
\text { level }\end{array}$ & $\begin{array}{l}\text { Influencing social } \\
\text { norms, behaviours } \\
\text { and practices in the } \\
\text { South and North } \\
\text { Defending/widening } \\
\text { civic space and } \\
\text { freedoms } \\
\text { Improving state } \\
\text { governance }\end{array}$ \\
\hline $\begin{array}{l}\text { Oxfam role } \\
\text { and voice }\end{array}$ & $\begin{array}{l}\text { Prominent } \\
\text { Oxfam role } \\
\text { and voice in } \\
\text { Western } \\
\text { Europe }\end{array}$ & $\begin{array}{l}\text { Supportive role to } \\
\text { CSOs in the South } \\
\text { Prominent Oxfam } \\
\text { role/voice in North }\end{array}$ & $\begin{array}{l}\text { Prominent Oxfam } \\
\text { voice/role in the } \\
\text { North and globally } \\
\text { Supportive role to } \\
\text { CSOs in South }\end{array}$ & $\begin{array}{l}\text { Supportive role to } \\
\text { CSOs in the South } \\
\text { Prominent Oxfam } \\
\text { voice/role on selected } \\
\text { issues where needed }\end{array}$ \\
\hline
\end{tabular}




\section{OXFAM'S ORIGINS: WORLD WAR II AND THE POST-WAR PERIOD}

A defining feature of INGOs' change models, including Oxfam's, that were established during this period was the provision of humanitarian aid to alleviate poverty and suffering (see Box 5). ${ }^{9}$ However, from the outset Oxfam had to accompany these efforts with policy influencing and public awareness-raising in order to address the causes of hunger. The initial intention of its founders was to raise money to provide food to the starving people of Greece. But they found that these efforts quickly embroiled them in controversial efforts to influence UK Prime Minister Winston Churchill to lift the Allied blockade of Nazi-occupied countries which was blocking the free passage of food into the country. They also sought to raise awareness and solicit donations from the public, despite a largely unsympathetic mood due to food shortages and wartime propaganda in the UK. Their influencing strategies and tactics - no doubt informed by previous historical campaigns - involved a mix of public awareness-raising (e.g. via public meetings, photo exhibitions and pamphlet distribution) and policy influencing (e.g. lobbying, letters to the press signed by distinguished academics and petitions to MPs) (Black, 1992). How Oxfam conceives of and implements 'influencing' has evolved since this time, but the same values of compassion and solidarity with suffering people that motivated its founders and many of its partners - as well as the culture of 'speaking truth to power' and its efforts to win a sometimes-unsympathetic public to its cause have been sustained over time.

\section{Box 5: INGO origins}

During World War II and in the immediate post-war period, a number of NGOs set themselves up as charitable organizations to provide relief and other humanitarian aid to vulnerable populations in Europe.

- Save the Children: giving aid to children in 'war-ravaged' central Europe from 1919

- Oxfam: efforts to provide relief aid to the people of Greece in 1942

- ActionAid: sponsorship of 88 children in 1942 to ensure access to health, sanitation, and agriculture in India and Kenya

- CARE: food packages given to millions of refugees in France in 1946.

When the Marshall Plan was launched in 1948, Oxfam shifted its attention to the alleviation of suffering in developing countries, initially including the Bihar famine and the mass exit of Palestinians after the creation of the state of Israel. Much of its subsequent humanitarian work took place in conflict scenarios and, as in wartime Britain, often involved complex negotiations with and influencing of state and non-state actors. In the UK, Oxfam continued trying to bring the issue of hunger to people's homes and communities through awareness-raising, fundraising events and creative hard-hitting social marketing. The first of its many shops opened in 1948, and they subsequently become a major source of funds, as well as an important awareness-raiser with the public (Black, 1992).

The post-war period also saw two monumental developments that left a lasting legacy:

- The establishment of the Bretton Woods institutions, the World Bank and the International Monetary Fund (IMF), which became large aid donors and subsequently, according to their critics, drivers of poverty and inequality through structural adjustment policies in the 1980s (Cornea et al, 1987).

- The 1948 Universal Declaration of Human Rights (preceeded eight months previously by the lesser known America Declaration of the Rights and Duties of Man driven by Latin American countries (Sikkink, 2015)). This became a 'common conscience' for humanity and 'a call to action, setting a high standard by which we judge the width of our generosity, the depth of our compassion, and the breadth of our humanity...sending a message that injustice anywhere is a threat to justice everywhere, and that no evil can last forever' (Brown, 2016). 
Many NGOs, activists and prominent civil rights leaders and movements subsequently drew inspiration from the Declaration. It has been used as a tool to speak out against injustices such as colonialism and apartheid, and to pressure governments to not only improve the lives of their own people but also to foster improved international relations and development for all (Stamatopoulou, 1998).

\section{PARTNERSHIP AND SOLIDARITY: 1950S TO 1970S}

International solidarity is not an act of charity. It is an act of unity between allies fighting on different terrains towards the same objective. The foremost of these objectives is to aid the development of humanity to the highest level possible.

Samora Moses Machel (1933-86)

Oxfam's work and relationships with communities, social movements and thought leaders in Africa, Asia and Latin America during this period contributed to a defining shift in its role, which has remained at the heart of its change model ever since. The shift can be characterized as a growing recognition of (a) the importance of campaigning to address the structural causes of poverty, as well as alleviating its symptoms through aid, and (b) the related understanding that it could achieve far more working together with partners and allies as part of a common movement, than on its own (Black, 1992). This new role was increasingly motivated as much by a sense of justice, for example about North-South inequality and the North's responsibility for poverty in the South, as it was by compassion.

The 1950s onwards saw the emergence and growth of national liberation struggles in Africa and Latin America, often supported by local movements of peasants, workers, students, women and/or indigenous peoples. In the 1960s, 17 former African colonies achieved independence. This occurred alongside a growing Marxist critique of the world capitalist system; the bottom-up development approaches of Tanzania's President Nyerere; participatory self-reliant democratic socialism; and the spread of the socialist movement in Latin America after the 1959 Cuban Revolution.

Governments in developing countries amplified their voices on the world stage with the establishment of the Group of 77 in 1972, the non-aligned movement and the rise of OPEC. The 1960s were marked as the 'UN Decade for Development', which set rich countries a target of $1 \%$ of Gross National Product (GNP) in aid. Key donors began to channel aid to INGOs, particularly to address the needs of vulnerable communities (Makoba, 2002).

During this period, Oxfam began to complement its emergency relief with funding for long-term development programmes in developing countries. The lessons it learned from working with local CSOs - combined with the ideas of thought leaders and change makers from the South such as Frantz Fanon, Paulo Freire and liberation theologians - raised new ideas and challenges about its vision and roles. Its programme work overseas increasingly focused on awareness raising, accompaniment to and capacity building of grassroots civil society organizations, and support for activism aimed at social change (Black, 1992). 
The Movimento dos Trabalhadores Rurais Sem Terra in recent decades has been one of the largest and most powerful social movements in Latin America. It legally occupies land that is not in productive or social use and thus subject to 'expropriation' by the government under the 1988 constitution. Through its actions over 350,000 small farming families have gained access to land. It has established food cooperatives; small agricultural industries based on local production; local schools; and an organization to provide its members with alternative education and health services. Its ethos is that there is no economic or social reason that impedes every Brazilian from having access to land, work, dignified housing, quality public schools, and food. But we need the courage to change our government, rethink economic policy and challenge the profits of the powerful.'

Source: MST website, http://www.mst.org.br/

In the North in the early 1960s, in response to increased demand, particularly from young people, Oxfam began to educate and mobilize the public to campaign against the structural causes of hunger. Locally based supporter groups and school organizers coordinated development appeals as part of the 'Freedom from Hunger' campaign. In 1963, Oxfam launched the 'Hunger £1 million' campaign, which enrolled support from the Beatles, other celebrities, the Daily Mail newspaper, and members of the UK Royal Family. The 'act local, think global' principles of the development education community, the domestic poverty programmes of newer Oxfam members - such as Oxfam Canada and Oxfam Australia's work with indigenous communities and Oxfam America's work with migrants - all subsequently reinforced this sense of a common global struggle against injustice. However, these shifts did not occur without a struggle. Campaigning was not initially allowed under UK charity law, and Oxfam was censured by the Charity Commission on a number of occasions, including for its support of the anti-apartheid struggle in South Africa (Black, 1992).

\section{Box 7: The Oxfam Confederation}

The name 'Oxfam' originally comes from Oxfam GB. Over time other NGOs have joined the family and new Oxfam affiliates created. In 1995 Oxfam International was formed with the aim of working together for greater impact to reduce poverty and injustice. Today, there are 19 member organizations of the Oxfam International confederation. They are based in: Australia, Belgium, Brazil, Canada, Denmark, France, Germany, Great Britain, Hong Kong, Ireland, India, Italy, Mexico, The Netherlands, New Zealand, Quebec, South Africa, Spain and the United States. The Oxfam International Secretariat is based in Nairobi, Kenya. The Secretariat runs offices in Addis Ababa, Oxford, Brussels, Geneva, New York, Moscow and Washington DC.

\section{Oxfam Canada}

Oxfam Canada's origins are deeply rooted in both influencing and solidarity work. The first project financed by Oxfam Canada after its establishment in 1962 was an emergency relief operation supporting First Nations in Northern Manitoba, which made national headlines and incurred the disapproval of the churches and of provincial and federal authorities which were seen as responsible for their welfare. Later, Oxfam Canada funded what was known as the 'talking bird', a float - or type of sea-plane which travelled across northern Canada providing services and recording conversations for radio broadcast as a way of fostering communications between distant First Nations' communities of the far north. The 'talking bird' was credited with helping to strengthen the activism and influence of First Nations peoples. The plane also transported many of the aboriginal politicians who advocated for land reclamations and aboriginal rights. In July 1971 , for example, the plane picked up aboriginal representatives from the north and took them to meet with representatives of the Anvil Mining Corporation to discuss concerns about the operation of the Carmacks Coal Mines located in the Yukon.

Source: Marshall and Sterparn, 2012. 
This period also saw the division of the world into US and Soviet camps, with the 'Third World' nations courted and pressured to join one or the other. By the end of the 1960s, there were development setbacks, with military dictatorships established in Latin America and Southeast Asia, followed by the overthrow of Chile's socialist leader, Salvador Allende, in 1973. The Nicaraguan revolution and overthrow of President Somoza in 1979 sparked repression in El Salvador and Guatemala. Within such countries local social movements and grassroots organizations often sprung up to help local people defend or realize their basic rights to liberty, life, land and health. Some Northern INGOs and solidarity groups to support them with financial and practical assistance and to advocate and campaign to improve their governments' aid and foreign policies. As one former Oxfam staff member interviewed for this paper explained: 'Oxfam sought to help those in need...It did not communicate, fundraise or lobby if not grounded in field work or a relationship with partners... reflecting the conviction that its credibility and legitimacy in advocacy rested on its practical experience'.

\section{Box 8: The role of research and evidence}

From the outset, Oxfam had used evidence from its programme to raise public awareness and reach governments. However, in 1963, Oxfam established an Information Department led by an economist, subsequently renamed as the Policy Department. Its initial role was to raise public awareness about hunger, but it also increasingly positioned Oxfam intellectually as an authoritative voice on development issues.

The principle of rigorous research with a human voice based on Oxfam's practical experience became an important feature of all subsequent advocacy and campaigns. The growing demand and pressure for evidence-informed policy in subsequent decades prompted further development of this function.

Sources: Black, 1992; Mayne et al, 2018.

\section{GLOBAL MOVEMENTS FOR CHANGE: 1980S TO 2000S}

This period saw Oxfam actively participate in global campaigns with partners and allies to reform the aid, trade and debt polices of Western-dominated multilateral institutions such as the IMF, World Bank and World Trade Organization (WTO). The policies were widely criticized by CSOs for being rigged in favour of rich countries, exacerbating poverty and inequality, and depriving poor countries of the policy tools that rich countries had used to develop.

Disillusionment about the development policies of newly independent governments had set in from the early 1970s, reflecting the complexities of development, disappointing results, and growing inequalities. The late 1980s saw the collapse of the Communist bloc and the Keynesian consensus, the spread and growing global dominance of free market (or 'neoliberal') economics, and an associated acceleration of economic globalization. The period also saw the intensification of the Third World debt crisis and the imposition of structural adjustment policies by the IMF and World Bank on debt-ridden countries.

Global deregulation and liberalization contributed to the growing power and mobility of capital and the weakening of organized labour (ILO 1995; ILO, 1996; George, 1990). Concurrently there was a continued growth of the new social movements that had emerged in the 1960s around gender, indigenous and environmental issues. Such movements began to find expression at the international level for example in the UN Decade for Women (1975-1985); the 1980 Brandt Report, which coined the terms 'Global North' and 'Global South'; and the first Earth Summit held in Rio in 1992. Oxfam's gender unit was established in 1986 to help mainstream gender into development planning and work with partners and the wider development sector to tackle gender injustice (Rowlands, 1997). 
Linked to these trends, there was increasing protest in the South about harmful impacts of the aid, debt, structural adjustment, trade and investment policies of northern governments and multilateral organisations. A loose global movement of southern, northern and international NGOs and CSOs formed with objectives ranging from radical policy reform to the total abolition of the IMF, World Bank and WTO. Their change strategies ranged from research and lobbying, to campaigning, to protests and direct action at high level meetings.

In the North, NGOs and CSOs intensified their campaigns on these issues assisted by publicity and celebrity action surrounding the 1984 Ethiopian famine. In the mid-1980s Oxfam GB launched its 'Hungry for Change' campaign (Clarke, 1985) highlighting the link between Western aid, debt, trade, African poverty and hunger and also strengthened its vital development education programme in the UK, which aimed to deepen young people's understanding of, commitment to, and willingness to make active responses on development and global justice issues. ${ }^{10}$ It subsequently set up a participatory research and advocacy programme with country programmes and partners focussed on structural adjustment and debt (e.g. Oxfam, 1995; Cornea et al, 1987). In Spain, Oxfam and other NGOs supported a strong national movement for ' $0.7 \%$ of GNI for aid', which included a hunger strike by social leaders, and led to an all-party agreement in favour of aid in 1994.

Increasing numbers of Oxfam affiliates also began to coordinate their global and national influencing efforts at this time, including via the Make Trade Fair campaign of the early 2000s (Watkins \& Fowler, 2002) and the Make Poverty History campaign ${ }^{11}$ from 2005. Then from the mid2000s Oxfam shifted the focus of its efforts to campaigning with allies for an arms trade treaty (Green \& MacDonald, 2015), the extractives industry and international climate change.

\section{Box 9: Social movements connecting across the South}

Third World Network, a southern based international NGO established in 1984, played a key role in providing policy analysis about trade, development and environmental issues as well as strengthening southern cooperation. In the early 1990s, other social movements in the Global South began placing greater emphasis on building connections and networks with movements in other countries and regions, and developing joint advocacy positions and campaigns. Via Campesina ${ }^{12}$ is a prominent example: it is a network of farmer, peasant and landless movements from five continents, started in 1993 by rural social movements in Latin America and then connecting globally. It has led global campaigns on the defence of native agricultural seeds, violence against rural women, the recognition of the rights of peasants, and agrarian reform.

Perhaps the most prominent space for such networking led from the South has been the World Social Forum, ${ }^{13}$ which began in the Brazilian city of Porto Alegre in 2001, and has since seen 15 further annual gatherings in different parts of the world. Social movements, initially from Latin America but later from other regions, led the coordination for this series of forums, which provide a pluralistic, diverse, non-governmental and non-partisan space for the exchange of ideas and alliance building. While easily dismissed by some as lacking clear purpose, such opportunities to exchange strategies, identify common struggles and build joint actions cannot be underestimated for many Southern social movements.

One of Oxfam's key influencing aims during this period was to tackle the structural causes of poverty by reforming government, multilateral and corporate policies and practices. Its strategy, given the dominance of neoliberal economic policy at the time, was to focus on selected 'wedge' policies - for example, the impact of WTO patent rules on access to medicines or WTO agricultural policies on small farmers - that exemplified systemic injustices and resonated with the public (Watkins, 2002; Bailey et al, 2001; Mayne, 2002). The logic was that winning change on a wedge issue would build public support and confidence to achieve further policy reform. While this strategy achieved some successes, Oxfam's role in the global movement was not without tensions. For example, whereas Oxfam believed that trade could be a positive force and sought to radically 
reform WTO trade rules through its Make Trade Fair campaign, other civil society groups believed the international trade regime was inherently harmful.

\section{Box 10: Multi-level influencing in Asia}

Oxfam's Asia region played an active role in both national and global influencing during this period, including:

- Participating in Oxfam's current global campaigns on inequality; food and climate change; and ending violence against women and girls;

- National advocacy and campaigning about the detrimental impact of trade rules on access to medicines to treat HIV/AIDS and other diseases in Thailand as part of the global campaign on access to medicines (2001 onwards);

- Supporting research on landmines, e.g. Oxfam Hong Kong publication of 'The Curse of the Bombies' by Jim Monan in English and Cantonese (1998);

- Producing a book on Landmines in Vietnam, both informing national organizations and contributing to the growing global campaign (1995-98);

- Establishing Action for Gender Relations Asia in all Asia country programmes to feed information to, and benefit from the assistance of, Oxford's Gender and Development Unit;

- Funding in-country research on the garment industry to inform local organizations and contribute to Oxfam's wider campaigning (1986-87);

- Supporting small groups and establishing a national coordinating body to enable landless people to benefit from the Government Land Reform Bill; this information was used by the central Oxfam GB team as part of a wider campaign (1985-87)

- Funding in-country research into Bangladesh's Essential Drug Policy linking it to a wider Oxfam campaign (1984-86)

Sources: Review and personal correspondence with Tricia Parker (country representative, Bangladesh 1984-87; Asia area coordinator/director, 1987-91; Oxfam Hong Kong country representative in Vietnam, 1991-95).

The primary target audiences for many campaigns during this period were the multilateral institutions and Northern governments which dominated global aid, debt and trade policies. Some CSOs also targeted or developed tactical alliances with southern governments, depending on their stance.

One area in which Oxfam sought to add value was through its targeting of powerful companies based in Northern countries (see Box 11). The influencing strategy in the Access to Medicines campaign entailed creating a powerful reputational risk via high profile media that companies could not ignore, challenging the intellectual foundations of corporate arguments and engaging financial investors to exert financial pressure on the companies.

\section{Box 11: The evolution of private sector influencing}

In the late 1970 s and early 1980 s, Oxfam had begun producing authoritative research about the effects of damaging practices of some companies producing pharmaceuticals, baby milk and pesticides on people living in poverty. During the Make Trade Fair campaign in the early 2000s, Oxfam publicly campaigned to reform the practices of powerful pharmaceutical and agricultural companies and subsequently began to engage and influence key extractive industries. Oxfam America and Oxfam Australia, for example, have long-standing programmes to support communities - especially indigenous populations - impacted by extractives, including guidance for companies about community consultation and grievance resolution, and have accumulated considerable knowledge and experience, including on how to conduct advocacy with companies. 
Over time, Oxfam's approach to the private sector has widened and become more sophisticated. Rather than engaging with and seeking to influence individual companies, it increasingly adopts a sectoral or multi-sectoral approach to drive more systemic change. For example, the 'Behind the Brands' campaign used scorecards to promote a 'race to the top' by ranking groups of companies against poverty-related indicators (on which companies were consulted) and using a mix of carrots and stick approaches via public engagement and private advocacy. The System Innovation for Women's Economic Empowerment (SIWEE) programme aims to achieve transformational change for women in agriculture and to shift attitudes and behaviours across the agricultural sector by pioneering a collaborative, actionoriented approach involving governments, companies, farmers and farmer organizations, women's organizations and civil society. More recently, Oxfam has been considering how to respond to and influence the increasing role of the private sector in Sustainable Development Goals (Mhlanga et al; 2018).

Oxfam's approach today often includes a mix of:

- influencing government rules that govern business;

- balancing insider and critical outsider influencing strategies with business; and

- collaborative and formal partnership approaches to drive systemic change.

Sources: Oxfam, 2017b; private sector, Oxfam International, retrieved from: https://www.oxfam.org/en/tags/privatesector;

The advent of email in the mid- to late-1990s prompted a step change in the coordination and tactics of national and international campaigning. The Zapatistas were one of the first movements in the Global South to globalize their struggle against neoliberalism through the creative use of the internet (as well as poetry, art and literature). ${ }^{14}$ Global campaigns against the OECD Multilateral Agreement on Investment and the Access to Medicines campaign from the mid-1990s to the mid2000s were built around email lists that enabled loose and relatively agile communications between campaigners around the world. Other global coalitions were more structured and centralized, such as the Global Call to Action Against Poverty (GCAP), which was founded in 2005 and grew into the largest anti-poverty campaign in the world by linking up and building on existing national campaign networks such as the Make Poverty History campaign in the UK.

Social media also helped CSOs mobilize publics around the world. Oxfam's and allies' global 'Big Noise' worldwide petition calling for governments to help end unfair trade practices received 17.8 million signatures by 2007 via a combination of online and offline methods. More than 23.5 million people around the world joined 'Stand up Against Poverty' events coordinated by GCAP and the UN Millennium campaign the same year. The period also saw a growing use of celebrities, ambassadors and other influential individuals to support causes. A number of high-profile artists, scientists and public figures were figureheads for Make Poverty History, which was opened with speeches by Nelson Mandela in London's Trafalgar Square in February 2005.

While some of the global campaigns were generally well received, the Make Poverty History campaign was criticised on the grounds that: debt, trade and aid play only a limited role in development compared with national factors, and at worst, do not work (Moyo, 2009; Birdsall et al, 2005); the approaches taken by donors and INGOs did not recognize the central role of national politics (Lockwood, 2006; Green, 2016) and neglected and undermined African leadership (Moyo, 2009); and that the simplified messages and celebrity voices failed to reflect the complexities of development. However, despite the campaign's admittedly ambitious name, its practical aim was to reform Northern and global policies and practices that were contributing to poverty in the South, rather than eradicate poverty in its entirety and taken together, the global campaigns of this period mobilized significant public concern and achieved some important changes on such issues (Crowson et al, 2009; Roodman, 2010). 


\section{THE WORLDWIDE INFLUENCING NETWORK: MID-2000S ONWARDS}

Since the mid-2000s, Oxfam has critically reassessed its advocacy and campaigning approaches in response to internal discussion, learning from partners and allies and the changing external context. This prompted efforts to rebalance its role and change model, including by seeking to:

- widen its influencing strategies to address more consistently the invisible and hidden, as well as visible, forms of power, such as social norms and behaviours, including a growing focus on tackling gender injustice;

- embed influencing more firmly into its humanitarian and development aid programmes as well as conducting issue-based campaigns;

- increase support for southern led influencing of Southern governments and regional organizations; as well as multilateral institutions and Northern governments.

- rebalance resources from centrally coordinated campaigns to Southern-led, decentralized campaigns;

- focus critiques on systemic failures such as gender injustice, inequality and climate change, and calling for an alternative human-oriented and sustainable economy (Oxfam, 2017), as well as specific policy reforms.

This period saw a continued global shift in economic and political power towards emerging economic powers in the South, including China, Russia, India, Brazil, South Africa and Mexico (Girvan, 2007). The global influence of some of these so-called 'BRICSAM' countries as donors increased, as well as South-to-South cooperation. There was also growing acknowledgement that changing the policies and laws of multilateral institutions and Northern governments was insufficient to achieve positive changes in the South, and that influencing strategies that worked in Northern or global contexts were not always appropriate in fragile or conflict contexts. Some Southern CSOs questioned INGOs' legitimacy to campaign on Southern issues and increased their own influencing efforts, for example around the BRICS meetings in 2014 and 2015; the G20 processes in 2014 and 2015; the Financing for Development conference in Addis Ababa in 2015; and the Sustainable Development Goals Adoption Summit in New York (Rodriguez, 2016).

In response to this shifting landscape, INGOs such as ActionAid, and subsequently Oxfam, sought to rebalance operations and influencing efforts towards the Global South, and to put a greater emphasis on national-level change by supporting influencing by local CSOs in the South and by encouraging the creation of Southern affiliates. The expectation was that improving the global and Southern balance of the Oxfam confederation would lead to greater legitimacy, influence and impact.

\section{Box 12: Oxfam's Southern affiliates}

In recent years, Oxfam affiliates have been established in Mexico, Brazil, India and South Africa. Oxfam also recently moved its international $\mathrm{HQ}$ to Nairobi. It is hoped that these moves will improve the global balance of the confederation, and lead to greater legitimacy, influence and impact. Just as Oxfam and partners may have influenced the European Union or the G7/G8 in the past, it hopes that this more decentralized model will enable it to work with and support Southern partners and allies to influence governments in the Global South directly. Through this emerging model, Oxfam has also increased its focus on working with and supporting southern civil society to influence the BRICSAMs, the G20, and multiple regional bodies and communities such as the Asian Infrastructure Investment Bank, ASEAN, ECOWAS and SADCC and multinational firms from emerging economies, often by supporting local civil society. 
The Southern affiliates are busy building their own national supporter and fundraising bases, including among emerging urban middle classes who are influential in shifting debates around poverty and inequality. Key questions for Oxfam include: what new partnerships with movements, CSOs and others does it need to invest in; how can it better work with large diaspora populations from these countries; how to take advantage of its international links to strengthen influencing and support Southern-led change; and what can it learn about influencing from the new affiliates?

The introduction of the UN Millennium Development Goals in 2000 and the Sustainable Development Goals (SDGs) in 2016 further focused influencing efforts on national-level change in the South and catalyzed the development of tactical alliances between domestic NGOs, INGOs and some governments (Maduraiveeran \& Muthuramalingam, 2017). The SDGs emphasized participatory social accountability and evaluation mechanisms at the national and local levels, effectively bringing INGO campaign approaches into the UN and governmental system. The explicit adoption of human rights-based approaches by many NGOs also strengthened the focus on governments - and increasingly companies - as duty bearers responsible for protecting and promoting peoples' rights (Foresti \& Ludi, 2007).

CSOs increased their use of digital campaigning strategies in the late 2000s. The 'Arab Spring', a wave of grassroots protests and demonstrations across the Middle East and North Africa, facilitated by social media, commenced in 2010. In Western countries, a range of new agile international social media and campaigning NGOs were set up, such as Avaaz, MoveOn, GetUp, and the SumofUs.

A growing number of national governments are imposing new restrictions on civic space through mass surveillance, martial law, states of emergency or even attacks on human rights defenders. As many as 64 states had adopted restrictive legislation on civic space since 2015 (ICNL, 2016). In response, NGOs including Oxfam have put greater emphasis on strategies defending and widening civic freedoms. These include strengthen civil society voices, improve governance, strengthen the accountability of CSOs to their publics, and convening and brokering between governments and marginal groups (Oxfam, 2017a).

The early-2010s saw the rise of 'fourth-wave feminism', which grew via social media and younger women's activism. In 2017, the Me Too movement further contributed to a sea change in the global understanding of gender injustice across society. In 2018 Oxfam's and the wider sector's own internal practices were questioned when incidents of sexual exploitation and abuse were highlighted by the media. This prompted a renewed organization-wide commitment to tackle power and gender imbalances within the organization and between Oxfam and the partners and people it works with.

The 2000s were also characterized by growing systemic challenges such as inequality and climate change and patriarchy, which exacerbated or constrained poverty reduction, and the corresponding growth and spread of systemic critiques and proposition of alternatives. Such critiques had been prevalent in some southern countries but now also took hold in the north. Additionally, academics from socio-psychological, behavioural, evolutionary, gender and environmental perspectives increasingly challenged the underpinning assumptions of neoliberal economics. Oxfam widened its own critique and began calling for a shift to a more 'human-oriented' and sustainable economy (Raworth, 2017), alongside continued calls for specific policy reforms. Oxfam's statistics and reports at the annual World Economic Forum in Davos, which demonstrate the obscene levels of global inequality, combined with national inequality reports, helped to make economic inequality a major global concern for international institutions and governments alike (see, for example, Hardoon, 2017; Lam, 2017). 


\section{PARTNERSHIPS AND ALLIANCES ARE ESSENTIAL FOR EFFECTIVE INFLUENCING}

Oxfam recognized early on that tackling the root causes of poverty, as well as alleviating its symptoms, requires a broad movement for change. This meant that the quality of its relationships with partners and allies ${ }^{15}$ would become central for effective influencing. Oxfam therefore works with a wide variety of organizations including: local project partners such as community groups, NGOs, cooperatives; campaign allies such as NGOs, environmental groups, trade unions, faith groups, traditional authorities, government or private sector allies, social movements; and strategic partnerships and multi-level stakeholder initiatives with different organizations. For example, in the run up to the G20 meetings in Turkey in 2015 , Oxfam brought together civil society representatives from more than 90 countries via online and offline platforms to discuss policy issues in relation to inequality, climate change, gender and governance.

Maintaining good quality relationships with partners and allies requires clarity and humility about Oxfam's own role and recognition that its work is shaped, and often only made possible, by the struggles and successes of others. It also means taking care not to take up spaces that domestic CSOs may want to occupy. Oxfam's internal influencing guidelines explain that the organization both speaks in its own voice as an independent actor and influencer, and seeks to strengthen and support local civil society, not displace it. They further state that:

- its roles should be identified in consultation with staff and partners, based on an assessment of the country-specific context and power analysis; and

- that it should only use its brand in Southern countries as a strategic tool when valued by partners and allies, and only when politically appropriate, or where it has set up Southern affiliates with the explicit aim of building a local Oxfam profile. (Oxfam National Influencing Guidelines, work in progress).

In practice, a 2018 meta-review of 24 of Oxfam's influencing strategies with allies and partners aimed at widening civil space and influencing policy over the period 2011-17 showed that in most cases of successful influencing, Oxfam was playing a supportive role to domestic CSOs; although in countries with more restrictive civic spaces, a prominent outsider role or voice from Oxfam was useful. (Shephard et al, 2018). The review defined 'widening civic space' as expanding political spaces within which CSOs and citizens can exert power and have their voices heard on policy topics, and 'changing policy' as bringing about change in the programmes, policies, procedures or budgets of the government. Similarly, a 2018 meta-review of Oxfam's work in Latin America and the Caribbean also found that Oxfam played a largely supportive role to partners in many influencing initiatives (Sanchez and Lenton, 2018). An example of this way of working is the global 'Enough' campaign which seeks to support the existing work of women's rights organizations on violence against women, and refrains from promoting its own brand if they think it could impinge on their spaces. Another concrete example is the Coalition Support Program in Vietnam (2012-16) which was partner-led and branded, with Oxfam's role as 'arms-length' support, which enabled coalition members to demonstrate their skill and authority in contributing to policy discussions (Brook et al, 2015).

Maintaining good relationships also requires their constant attention and renewal (Lejeune and Winder, 2016). Oxfam has committed to a set of Partnership Principles, including shared vision, transparency, mutual accountability and joint learning (Oxfam, 2012; Oxfam, 2016c). However, translating these principles into practice is a challenge, as found by a 2014 partnership survey (Keystone, 2014). Some of the issues about partnership raised by partners and staff interviewed for this paper include: 
- Voice and roles: Some Southern CSOs fear that INGOs crowd them out or question their legitimacy to speak about Southern issues. Others welcome Oxfam's voice and influence, particularly at the global level, and caution against it giving up its power. As one respondent from a Southern-based INGO pointed out: 'Oxfam is the biggest name in development and has the power to shape issues.' Similarly, a respondent from an international trade union added, 'Looking forward it's important that Oxfam acknowledges the power of its own name - when Oxfam speaks, people listen'. Or as another interviewee put it: 'on some issues, it's good for Oxfam to take the lead, on others better to ally with specialized organizations'. Getting the balance right for operational INGOs is trickier than for non-operational ones whose main role is to support their partners' programmes and influencing initiatives.

- Power imbalances: Oxfam requires all its campaigns to adhere to an agreed set of standards to build meaningful stakeholder participation and accountability in their design, implementation and review. Yet Oxfam's global reach, size and funding role creates power imbalances with smaller scale partners, which can constrain authentic participation or feedback. Mitigating power imbalances requires improvements to institutional cultures and practice and adherence to partnership principles as well as personal humility, listening, brokering and conflict resolution skills among staff.

- Ways of working: Partners value long-term relationships, so Oxfam's tendency to shift between campaigns every five years can be problematic, particularly if there is no proper exit strategy, or if Oxfam takes up issues in a high-profile way that others have been working on for years. One external interviewee suggested that, 'Other groups make it into an emerging issue and then Oxfam joins in and takes a leadership role. Other CSOs are not very happy as Oxfam jumps in, gets the highlight and then jumps out. Maybe it reflects funding and public engagement needs. But it means Oxfam rides a wave and then abandons it'. In addition, as explored below, Oxfam's procedures, donor reporting and legal requirements can make it difficult for it to fund and support unregistered smaller or informal NGOs or social movements that are already working on these issues.

- Risk: In many cases, it is right for INGOs to support domestic CSOs to do the influencing themselves. However, many people in South America, Asia and Africa have lost their liberty or lives promoting the interests of the poor or tackling culturally sensitive human rights violations. INGOs therefore need to take care not to simply transfer risk, and be prepared to stand by, support, speak out and defend partners over time

\section{ADVOCACY AND CAMPAIGNING CAN ACHIEVE CHANGE AT SCALE}

Over recent years a body of evidence has been built up that demonstrates the ability of advocacy and campaigning to influence government and corporate policy. To cite a few recent examples:

- The 2018 meta-review of Oxfam's, partners' and allies' citizens' voice and policy-influencing initiatives at national and regional levels found that 15 out of 22 cases successfully expanded civic space, ${ }^{16}$ and eight out of 15 cases successfully changed government policy on povertyrelated issues ranging from health to gender equality, climate change, and land rights (Shephard et al, 2018).

- A 2018 meta-review of Oxfam's work with partners and allies in Latin America and the Caribbean also found a range of influencing successes, including: raised awareness and strengthened influencing capacity of the most vulnerable sections of the population about their rights; strengthened capacity and ambition of women to participate in decision making spaces; and progress in legislation on women's rights. The evaluation also recognized the importance of Oxfam's role and added value as a convener, catalyst, facilitator; and its ability to project agendas from the local level to global, through campaigns and the use of emblematic cases and new research. (Sanchez and Lenton, 2018). 
- A 2017 meta-review of Oxfam's and partners' women's empowerment projects found they have a positive and statistically significant effect on women's empowerment, although they can be linked to episodes of violence, highlighting the importance of incorporating strategies to minimize such effects (Lombardini, 2017).

- A 2013 external evaluation of the Raising her Voice (RHV) programme contributed to legal successes across 17 countries, including contributions to ten new laws to prevent and protect against gender-based violence, and nine laws on a wider spectrum of women's rights (Beardon \& Otero, 2013).

\section{Box 13: Achievements of local and national influencing initiatives in the Philippines}

The Philippines is one of the country's most vulnerable to climate change, due to its exposure to climate-related risks and the low adaptive capacities of a significant portion of its population. In recent years, Oxfam and its Philippine partners have:

- Worked in eight provinces in the southern Philippines to help local communities to adapt to the impacts of climate change;

- Supported lowland and upland farmers and fishers to gain access to climate-smart technologies, and develop science-based adaptation and risk-reduction plans and budgets;

- Achieved a number of significant policy wins, such as the Philippine Department of Agriculture's allocation of millions of pesos to promote its sustainable organic agriculture programme, and national legislation creating the People's Survival Fund, an annual rolling government adaptation budget intended for local government units and accredited local organizations to implement climate change adaptation projects;

- Helped develop the National Framework Strategy on Climate Change and the National Climate Change Action Plan, which laid down the country's strategy to combat climate change;

- In 2011, Oxfam and its partner the ICSC, together with a wider civil society coalition on climate change and congressional allies developed an adaptation finance bill that was envisaged as a special trust account designed to address the gap in adaptation financing by coordinating the scattered Climate Change Adaptation and Disaster Risk Reduction funding streams. This bill, now referred to as the People's Survival Fund, was rapidly enacted into law in 2011.

- In 2018, the City Government of Tacloban amended its Gender and Development (GAD) Code to provide a legal definition of 'unpaid care' and the corresponding obligation to include unpaid care issues in all planning, budgeting, and programming activities for identified priorities such as housing and land use; comprehensive services for women affected by disasters and calamities; community-based conflict resolution structures; and access to care-supporting infrastructure and services, such as childcare centres, market roads, and labour market programmes for women.

Sources: Oxfam, 2018b; Morchain, 2016

The global justice movement that developed from the 1980s onwards achieved some important wins with advocacy and campaigning at a global level. Some successes include:

- By the late 1990s, Southern debt had become one of the most significant global issues, due to the global Jubilee 2000 campaign. Between 2000 and 2015, the campaign won $\$ 130 \mathrm{bn}$ of debt cancellation for developing countries (Roodman, 2010; Jubilee Debt Campaign, undated).

- The OECD Multilateral Agreement on Investment ${ }^{17}$ was defeated in 1998 by a global coalition of CSOs and France's decision not to support it (Picciotto and Mayne, 1999).

- The Access to Medicines Campaign, launched in 2001, contributed to a 98\% reduction in prices for life-saving HIV medicines (from around $\$ 10,000$ to around \$80) (Mayne, 2002; Bailey et al, 2001). In early 2000 only a tiny handful of people in low and middle income countries were able to afford access to ARV treatment compared to an estimated 6.6 million people by the end of 
2010 - nearly half of those eligible. (UNAIDs, 2011)

- The Control Arms campaign resulted in an international treaty to restrict arms sales to poor countries in 2013 (Green \& MacDonald, 2015). This built on the experience of earlier campaigns that resulted in treaties banning landmines (1997) and cluster munitions (2008).

Advocacy and efforts need to be further strengthened if they are to help address the current profound development challenges. The 2018 meta-review of Oxfam's work in Latin America and Caribbean, for example, identified various design challenges for influencing related to weak power analysis, shaky change strategies and lack of agility, although many challenges also related to external constraints such as power imbalances, shrinking civic space and backlash from powerful actors (Sanchez and Alexandra,2018). More widely, as we discuss below, civil society organizations need to work together to prioritize and collectively address key root causes of poverty.

\section{THERE IS NO ONE-SIZE-FITS-ALL APPROACH TO INFLUENCING}

Although civil society advocacy and campaigning can help to achieve change in parliamentary democracies, they are not necessarily appropriate strategies in other contexts. Oxfam's partners and allies have developed a wide and creative range of influencing strategies adapted to the diverse contexts where they work. Where governments are dictatorial, corrupt or weak, it may make better sense for them to strengthen social movements, widen civic space and build alternatives from the bottom up. In restricted or conflict zones, it may be more appropriate to first create safe spaces for dialogue between communities and authorities (see Box 14) or help legitimize civil society (Oxfam, 2017a).

\section{Box 14: DRC protection committees}

In the Democratic Republic of Congo (DRC), in the context of many years of armed conflict, Oxfam and partners have helped to set up and support elected community protection structures. These consist of a Community Protection Committee (six women and six men), a Women's Forum ( 15 women) and a group of 'Change Agents' (10 women and 10 men). The latter analyse the security situation in their own communities, prioritize issues and identify selfprotection measures and other actions that could make change happen, including through dialogue with local civil, police and military authorities. The protection committees help to strengthen individuals' agency and the groups' capacity to influence the practices of local civil policy and military authorities and reduce human rights abuses.

Source: Personal correspondence; Oxfam DRC protection strategy (2015-2020) and various project documents (internal).

As one former Oxfam staff member said about the Make Trade Fair campaign of the early 2000s: 'What played out was a Western parliamentary way of understanding how change happens - i.e. mobilization of grassroots in order to increase leverage of politicians who would in turn take action in policy. This put together with research would give rise to change... For many countries, this didn't work - corruption meant that political parties were not considered a viable vehicle for mobilization... some progressive organizations thought that markets were bad and didn't want to engage, so they either sought opposition and alternatives to neoliberal rules, rather than reforming them'. Nevertheless, 'little by little, people did engage with the trade agenda and people shifted. They began to see the implications of trade rules and supply chains, e.g. for coffee producers, and that it complemented national work strengthening producers. It was quite transformational.' 


\section{CHANGING POLICIES IS NOT ALWAYS ENOUGH}

In some cases, advocacy and campaigning to change visible laws and policies can bring immediate large-scale benefits to people on the ground. But in other cases, additional change strategies are required to ensure that policy changes are actually implemented. One illustration of this challenge is the fact that more than 125 countries have some sort of legislation on violence against women and girls, yet it remains a prevalent problem (Hughes, 2017).

Closing the policy implementation gap can require long-term influencing efforts by domestic CSOs to hold governments to account, for example via budget monitoring. As one interviewee put it: 'The theory of change is that if policy changes then everything changes. But this doesn't work in practice! It takes 20-50 years for a policy to be implemented. Who will make sure the government does it?'

\section{Box 15: Strengthening local civil society leadership and voice in Honduras}

The Raising her Voice campaign in Honduras has made notable gains in an extremely challenging context. Political instability has limited partners' opportunities to work at the national level. One of the strategies is therefore to build a strong grassroots network of women activists to hold the authorities to account and ensure that the government does not reverse hard-won progress on women's rights. The project has worked directly with more than 2,200 women from marginalized urban and rural communities, increasing their leadership skills through training in advocacy, public speaking and budget monitoring.

In the target communities, around 1,800 rural women have raised demands at their local assembly, a noteworthy achievement at a time when women's participation in formal governance structures is in decline. In one municipality, women's groups have successfully lobbied for a local law to prevent domestic violence. In four other municipalities, women have secured public investment for women's organizations. The number of women reporting incidences of violence is increasing at municipal level, as women become more confident that they will be taken seriously.

Source: Raising Her Voice, 2011

Policy implementation may also require additional strategies to influence the cultural beliefs, social norms and behaviours of public officials and citizens. The worldwide Enough campaign, for example, is seeking to tackle and transform social norms that perpetuate poverty and injustice or constrain policy implementation, including the machismo norms surrounding young love in Bolivia; the legitimization of violence and racism against indigenous women in Guatemala; violence against women through art and films in Morocco; the acceptance of intimate partner violence in India; and early forced marriage in Indonesia (Oxfam, 2016a).

\section{THE IMPORTANCE OF CONTEXT, POWER AND SYSTEM ANALYSES}

The concept of influencing offers the potential for increased relevance and effectiveness in tackling the causes of poverty, due to the wide range of strategies on offer. But in practice, much depends on how staff interpret and use it. To ensure effective influencing, it is important for Oxfam that its objective remains explicitly linked to addressing the structural causes of poverty, including unequal power relations. It is also important that influencing strategies are informed by sound and regular context and power analysis that identifies hidden and invisible, as well as visible, forms of power and that also monitors changes in the wider system. 
Increasingly, power analyses conducted by Oxfam staff assess civic space and look beyond formal and visible expressions of power to identify traditional, informal and invisible power (Rowlands, 2016). Several programmes - such as Women's Economic Empowerment and Care (WE-Care) use this information to help them transform the cultural beliefs and norms that prevent women's full participation in economic and public life. There are also recent efforts to better understand and tackle state capture by vested interest. However, while the acceptance, use and sophistication of power analysis is growing in Oxfam, it is not yet used consistently or regularly (Sanchez and Lenton, 2018; Rowlands, 2016), nor is there always sufficient awareness of the wider system of which influencing efforts are often only one small part (Green, 2016).

\section{Box 16: WE-Care initiative power and context analysis}

WE-Care's context analysis looks beyond the available evidence on unpaid care to also examine wider social, economic and political factors. This could include: social norms and expectations around care roles; current patterns of care provision; religious and cultural factors influencing care; women's and men's livelihood opportunities; budgetary, financial and economic considerations; and the analysis of the political context at local, regional and national levels.

Its power analysis builds on the context analysis to identify which individuals, organizations and institutions have the power to make change (or to block it) in any given context, as well as the individuals, groups and departments that might help influence them. WE-Care's influencing audiences and allies have included parliamentarians; government officials; women's rights organizations; religious, cultural and traditional leaders; youth groups; private sector companies; media outlets; and CSOs.

\section{THE MIX, TIMING AND SEQUENCING OF INFLUENCING STRATEGIES AND TACTICS MATTERS}

Getting the right mix of influencing strategies and tactics is important. In relation to policy influencing, for example, the findings of the recent meta-review of Oxfam's and partners' national and regional citizens' voice and policy influencing initiatives (Shephard et al, 2018) found that:

- To change policy, it helps to have first expanded civic space. Among the 13 reviewed initiatives that sought to simultaneously strengthen domestic civil society voice and expand the political space for them to exert influence and change policy ${ }^{18}$, only one successfully changed policy without also having widened civic space for domestic organizations. Influencing tactics that strengthen networks and alliances, and create spaces for dialogue, between domestic civil society and establishment allies were highlighted as particularly effective (Shephard et al, 2018). For instance, the Coalitions Support Program in Vietnam supported civil society, media, academic, and in some case state and business champions, to work together on key policy issues of public concern. The programme's theory of change aimed to 'unsettle' normal decision-making processes and create new ways of designing and delivering policies (Sidel, 2015).

- However, the successful expansion of civic space on its own does not guarantee policy change. Only half of the ten cases that were successful at expanding civic space were also successful at changing policy. In other words, access to decision makers does not necessarily equate with influence: other strategies are needed.

- Linked to this insider influencing tactics are a necessary but not sufficient condition to change policy or widen civic space. To be effective, insider strategies (e.g. involving building relationships and alliances with target audiences, the presentation of evidence on impacts and solutions, dialogue and lobbying) need to be accompanied by other tactics, including: 
- those that capitalize on windows of opportunity (e.g. caused by elections, civil society campaigns, disasters);

- those that make use of outsider strategies (e.g. media pressure, popular mobilization and protests); and/or

- those that use multi-level influencing or forum shifting.

\section{Box 17: Oxfam's influencing work in Latin America and the Caribbean}

A recent meta-review of Oxfam's work in Latin America and the Caribbean found that in relation to influencing, the strategies that produced the best results were characterized by:

- a diverse and representative selection of actors with complementary areas of knowledge;

- accompaniment shaped to fit the actors, combining organizational strengthening with specific training, often on components of advocacy and digital campaigns;

- demands rooted in proposals that emerge from the local level, are informed by learning from practice and are linked to pressing needs;

- reliable research and generation of evidence;

- ongoing context monitoring to respond to new opportunities;

- innovation in communications and mobilization strategies;

- keeping a good balance between local, national, and ideally international levels;

- in hostile environments, knowing when to keep a low profile, continually updating the theory of change, seeking out new alliances, and becoming more creative.

Source: Sanchez and Lenton, 2018.

Influencing strategies and tactics also need to be tailored to the different stages of the policy cycle. Influencing the terms of debate in order to widen policy space for future reform requires different influencing strategies and tactics from those needed to move an issue up the policy agenda or change, implement and monitor a policy (Green, 2016). Careful framing and use of evidence and communication messages are important (Mayne et al, 2018).

Timing is also key. Both theory and evidence show the importance of monitoring and responding agilely to windows of opportunity caused by wider contextual or system changes (Cairney, 2018; Shephard et al, 2018). Sequencing also matters. Evidence indicates that successful governmentto-government influencing entails an escalating mix - or pyramid - of rewards and sanctions starting with 'persuasion' (dialogue, reciprocity and modelling solutions) then shifting to the threat of 'pressure' (e.g. naming and shaming), the use of pressure, the threat of 'coercive strategies' (such as trade sanctions) and then the use of 'coercive' strategies as a last resort. The sequence starts with persuasive methods as this is more efficient and less disruptive to relationships than more coercive strategies. Additionally, the threat of pressure or coercion can be as effective as its actual use. Such sequencing can be usefully adapted for use by NGOs although they have different power sources (Braithwaite, 2004; Braithwaite \& Drahos, 2000).

An important corollary of these findings is that to ensure effective influencing CSOs also require the ability to manage the tensions and potential backlash that can result from combining insider and outsider strategies. Strategies to legitimize CSOs; to provide targets with an opportunity to respond to criticism before going public; reframing communication messages to avoid stigmatization and allow them the possibility of future improvement (rather than stigmatizing them), can help reduce backlash and ensure success (Sahan,2016; Braithwaite, 2002).

There is also growing awareness in the sector about the importance of behaviour change in tackling poverty and injustice, whether to help end violence against women girls, influence health and sanitation or environmental behaviours, help close the policy implementation gap, or motivate policy makers and the public to take action. Again, the types and mix of strategies and tactics 
matters. Traditionally many behavioural interventions assumed that providing information would change attitudes and beliefs and hence change behaviours, or that the provision of technical infrastructure would suffice. There is now increasing awareness about the need to also address the emotional, social and cultural influences that shape our behaviours (Mayne et al, 2017).

\section{SOCIAL MOVEMENTS AND LOCAL ASSOCIATIONS PLAY IMPORTANT POVERTY REDUCTION ROLES}

Social movements, grassroots associations (Gaventa \& Barrett, 2010) and women's rights organizations (Htun \& Weldon, 2012) have been found to be key drivers of change. From South Africa's anti-apartheid movement, to Bolivia's indigenous movement, to the women's movement in Colombia, to Tunisia's Jasmine Revolution, to the Chilean students' movement, to the Indignados ('Outraged') Movement in Spain, to Black Lives Matter in the US, they can play crucial roles in helping people claim their rights or reduce poverty, whether defending and improving the rights of workers or women; protecting indigenous and small farmers against land grabs; ending racial or gender discrimination and violence; defending and improving civil and political rights; improving services and access to them; toppling repressive governments and dictators; or promoting peace.

Working with and supporting social movements and grass roots groups can therefore be an important way of reducing poverty and injustice. However, it can be difficult for NGOs to fund them if they are not formally registered. From the 1950s to the 1970s, Oxfam was able to work with and support community associations and social movements relatively fluidly. But increased donor focus on short-term measurable results (Edwards, 2014), combined with the tightening up of INGO's ways of working, can make it harder to do so now. As one person said when commenting on this paper, 'a key learning from Asia is that our systems, such as our contract setup and compliance procedures, are just not adaptable enough to ensure agility, take advantage of opportunities and foster good relationships with partners. It's a major constraint'.

\section{Box 18: Colombia's social movement}

Colombia is an example of a country that has built and maintained a strong and extraordinarily resilient social movement in the face of decades of extreme political violence. In a historic move, Colombia's national peace agreement was finally signed on 24 November 2016. Although the peace agreement is now facing challenges, women's organizations, including rural women, actively contributed to getting it signed and the inclusion of gender agreements. The women's rights organizations had not initially been involved in the peace talks. But as a collective, and with international support, the women's movement lobbied the government to open the talks to women, giving their representatives official status in 2014. In the postagreement phase, Oxfam's partner, Colombian Platform for Rural Women obtained a space in the gender work of the commission to follow up on the implementation of the agreement. Their influencing achievements included:

- Increased access to formal decision-making spaces: through the creation of the Office for Rural Women within the Ministry of Agriculture;

- Gender-sensitive policy: within the National Development Plan, a new public policy (article 232) specifically for rural women was achieved through successful lobbying of the national Congress by the Platform;

- More rural women in influential leadership roles: Platform members were appointed to head up the Office for Rural Women, potentially increasing opportunities to influence national policies and agenda setting;

- Shifting social norms: the process changed public perceptions of rural women, shifting the narrative from one of invisible and faceless victims to one in which their value, leadership and contribution is recognized and respected; 
- Blocking regressive policies: Planned government projects and policies related to land ownership and rural issues were blocked by the action of the social movement and organized rural women;

- Growing the movement for change: Platform partners around the country are replicating the successful advocacy approaches and coordinating joint initiatives without Oxfam, thanks to its prior investment in developing capacities for network and alliance building, knowledge exchange and joint advocacy action;

- Young feminists coming together: International and national support was secured for the needs of young women from urban and rural schools who had participated in a yearlong young peace builders project.

Source: Oxfam (2018c) 


\section{FUTURE OPPORTUNITIES AND CHALLENGES}

There have been big developmental advances over recent decades. Absolute poverty levels have fallen around the world, and human development indicators have risen. There are significant new influencing, networking and organisational opportunities linked to new ICTs (Castells, 1996; Braithwaite and Drahos, 2000; Jeremy Rifkin, 2014; Timms and Heimans, 2018). The current widespread public disenchantment with neoliberal policies (Galasso et al. 2017) also offers a major potential opportunity to influence and drive positive change.

However, the world is also facing profound challenges of gender injustice; extreme inequality of wealth and power; climate breakdown and ecological destruction; mass migration and refugee movements; the rise of chauvinist nationalism and authoritarianism; and attacks on civil society. Such challenges may exacerbate poverty, constrain its reduction or result from it. INGOs themselves are facing a series of challenges that some have described as representing an existential threat (Edwards, 2016). We explore a number of these challenges and opportunities below.

\section{Box 19: 'Fake news'}

'Fake news' and the decline in trust of experts (Edleman, 2017) pose new challenges for evidence-based influencing work for the public and governments, although recent evidence suggests these trends may be stalling (Edleman, 2018). Nevertheless, Oxfam's experience is that an underpinning of sound evidence remains critical for credible influencing, even though only a fraction of it may be presented to target audiences. Developing relationships with targets and involving relevant stakeholders in research (particularly those affected by the research but also target audiences); tailoring research to the task; carefully framing and communicating; using appropriate messengers; using careful timing; and adapting the presentation of evidence in line with windows of opportunities can all help ensure success.

Source: Cairney, 2018

\section{SYSTEMIC CHALLENGES}

Poverty, extreme inequality, climate change and gender injustice have deep structural or systemic causes so are very difficult to address. External influences - both sudden and long-term - such as urbanization, technological innovation, market forces, moral panics and wars are often the major drivers of structural, system or societal change (Green, 2016a; Green, 2017). But civil society-led campaigns can also contribute to such change, a notable example being the abolition of the slave trade. Many CSO campaigns focus on influencing the powerful individuals, interest groups and institutions that oppose changes to the status quo. Yet societal or systemic problems may also be maintained by a range of other political, social, economic and technological influences:

- at the individual level e.g. attitudes and beliefs, unconscious mental shortcuts, motivations (values, mental frames and emotions), identities, personal agency and behaviours;

- at the relational level e.g. social norms, peers, role models, social identify and reference groups (standards and sanctions);

- at the institutional level e.g. internal cultures, incentives and practices; and 
- at the societal level e.g. government policies, vested interests, dominant ideologies, markets, technologies and infrastructure, socio-economic factors.

Addressing the structural causes of poverty therefore entails the identification and prioritisation of key influences and the use of coordinated and sustained multi-level and multi-pronged strategies to address them. This in turn makes the building of broad-based national alliances between different civil society, establishment, business and other organisations even more important (Gaventa, 2010). Additionally, as many systemic problems are also global in scope, building international alliances also remains critical. In both respects, there is much to be learned from the global movements of the 1980s-2000s, including the cross-sectoral and cross-national coalitions formed in Mexico, the US and Canada, which brought together workers, farmers, women and indigenous peoples to agree and campaign on a common platform of reform for the North American Free Trade Agreement in the 1990s.

\section{Box 20: Unusual alliances in the Philippines}

Campaigns often build alliances with other CSOs and to a lesser extent with establishment allies. Yet this excludes other important potential allies such as traditional chiefs, customary leaders, police, military personnel, peacekeepers, local associations, religious leaders, vigilantes, local healers, and locally elected councils. For example, in the Philippines, Oxfam and its WE-Care implementing partner, Community Organizers Multiversity, worked with Imams and other religious and cultural leaders to promote shared care between women and men (see Box 16). Dialogues with Imams, Ustadjas and Muftis were initiated in Mindanao in the south of the country to raise awareness of unpaid care issues. The team found that codeveloping materials for use in Friday prayers made it easy for them to disseminate care messages.

Source: Fooks, 2018; internal case stories from Patricia Miranda.

Continual testing and adapting of influencing strategies in line with changing contexts can also help, as well as learning from other 'successful strategists', whether from civil society allies, the establishment, right-wing populists or faith organizations.

\section{SPREADING AND SCALING UP SOLUTIONS}

There are plenty of alternative approaches and solutions but to address the structural or systemic causes of poverty, NGOs will need to get better at spreading and scaling them up. History and social science provide many examples of where 'niche' innovations - such as new forms of transport, sanitation, food, lighting and electricity or related behaviours - have taken off and spread when exogenous events (such as economic crisis, war or natural disasters) put pressure on dominant policies and practices and open windows for change (Geels \& Schot, 2007;

Kingdon,2003; Green, 2017). ${ }^{19}$ The same can happen with community grassroots solutions (Smith \& Seyfang, 2013; Sternin et al, 2010). For example, in one county in the UK pressures from local flooding combined with a more favourable national policy framework linked to climate change, enabled an upsurge and subsequent scaling up of successful grassroots carbon reduction innovations. (Hamilton et al., 2015). 
To exploit such windows of opportunities, NGOs and others will need to invest in:

- pioneering, identifying, nurturing and testing solutions (Kemp et al, 1998);

- standing ready to influence important individuals and institutions - including governments - to adopt, support and promote them when windows of opportunity arise (Cairney, 2018; Carter et al, 2018); and

- modelling and spreading them through social networks, partnerships, shared and social learning processes, and peer-to-peer mentoring (Carter et al, 2018).

In Tajikistan, for example, Oxfam and partners led the development of a replicable model for rural water supply and management run by local water user associations linked to local governance structures (Goodrich, 2017). This model is promoted, alongside other policy and practice influencing, through a national water and sanitation stakeholder group convened by Oxfam.

\section{NEW FORMS OF ORGANIZING AND CIVIC FREEDOMS}

Political and environmental challenges are driving new forms of civic activism. A largely urban and youth-led cohort is creatively using new technologies and traditional identities to challenge unjust systems (Youngs, 2007). Workers are also increasingly successfully using social media to coordinate action and campaigns, including the creation of new digital services which helps workers compare working conditions, articulate and spread their demands or crowd-fund legal actions (Economist, 2018). In many countries, this activism takes the form of informal or online networks, bypassing the institutional (and funding) structures of NGOs. These civic activists demonstrate the potential of new ways of mobilizing - with a dynamism that may leave INGOs behind if they do not adapt. As one staff member commenting on this paper said: 'We are not only struggling to keep up, we are struggling to even open a dialogue with such groups. It feels to me like there is a chasm between our "development" world, and that of new, emerging social movements that view development in such different ways - often combining activism with recreation, art, music, lifestyle choices, study, etc.'

Yet civic activism also faces challenges such as fragmentation between single issues and changing funding landscapes. Additionally, while NGOs' digital campaigning has facilitated protests and movements it has not seemed able to win over wide sections of the public, as seen by the rise of right-wing populism (Galasso et al, 2017). In some contexts, digital campaigning appears to be facing diminishing returns, due to the overcrowding of digital communication channels and the shallower levels of participation compared with face-to-face dialogue (Galasso et al, 2017; Van Stekelenburg et al 2016). New blended forms of online and offline engagement and organisation, as well as investment in training mentoring will be needed to cultivate active citizenship at scale (Hahn, 2014; Oxfam, 2018d). 
In Peru, the Oxfam team applies what they call a magnet model of influencing. Like a magnet, inequality and fiscal justice act as common denominators; key themes which 'attract' and connect different actors and agendas. The magnet approach is based on the premise that to do effective influencing, you need to:

- engage people by relating current events and issues that they care about with inequality;

- blend online public engagement with offline inclusive participatory active citizenship processes;

- link together different actors, such as young people's activist groups, traditional civil society, newer emerging movements, investigative journalists and alternative media to propose and frame counter-narratives and demands which swim against conservative mainstream currents.

The Oxfam team does this offline through 'Actúa.pe Inequality LABs': capacity building and strategy design spaces to link youth and other activists, experts, evidence, practical tools and tactics. The LABs help strengthen youth activism and amplify their voice by putting them on an equal footing with experts who are developing related research and leading diverse agendas and struggles.

Using the unbranded online portal 'Actúa.pe', the communications team, along with other key online influencers, weave counter narratives with facts, humour, pop culture references and a Peruvian flavour - a meme-based form of popular communication. These memes get normal citizens talking about inequality, fiscal justice and gender. They also attract the attention of decision makers, showing activists that that power holders can be made to listen.

The Oxfam team in Peru complements this active citizenship work with traditional direct lobbying of Congress, using compelling evidence from investigative journalist groups, NGOs, and academics. A recent powerful example of the magnet model in action has been the campaign for tax justice on women's health (\#ShePays) which managed to connect two problems that are not usually viewed as connected: tax exemptions for big Pharma in Peru and women's access to treatment of cervical and breast cancer. Their compelling narrative and their lobbying of Congress have contributed to the mobilization of Congress and ordinary people so that tax authorities investigate the tax breaks and tax dodging practices of the main big Pharma companies.

Source: Oxfam, 2018d

Additionally, states and corporations can combine the same information and communication technologies with more conventional forms of power in order to shrink civic space and freedoms. Influencing in such contexts carries the risk of backlash by changing power dynamics, highlighting otherwise hidden conflicts or accelerating the pace of change. INGOs which support influencing by their partners in such contexts bear a special and significant responsibility for helping to protect them. This may entail, for example:

- helping them to anticipate counter-measures and backlash;

- bearing witness, becoming human rights defenders themselves or supporting others to do so;

- convening safe spaces between governments and civil society groups for dialogue;

- acting as ambassadors for local organizations when they cannot speak out themselves;

- helping to legitimize and increase understanding of civil and military authorities about the important poverty reduction roles of CSOs and social movements; and

- facilitating shared spaces for local NGOs to exchange strategies about how to defend (Dunmore-Rodriguez, 2018; Oxfam 2017a). 
In Myanmar, for example, Oxfam helped build and legitimize local CSOs, which in turn successfully expanded the participation, especially of women, in local governance (van Hemelrijck, 2017). It may also entail influencing or working with busines to support civic freedoms and human rights defenders (Bennet et al,2018).

\section{TRUST, LEGITIMACY AND ACCOUNTABILITY}

Trust, legitimacy and accountability are important in their own right, but also important for credible influencing along with an organization's actual or perceived authority, competence, integrity (alignment between values and practice), independence and the quality of its relationships. They are also important for the defence and widening of civic space and freedoms (Edwards, 2005). However, public trust in business, government, NGOs and media has declined broadly in recent years (Edelman, 2017). Trust in the aid sector was further dented in 2018 due to questions and revelations about its safeguarding practices. Local CSOs also face issues of trust. A 2018 report by the Carnegie Institute (Brechenmacher \& Carothers, 2018) highlighted how some governments are justifying new restrictions on civic space by accusing local CSOs of being: self-appointed; accountable to external rather than domestic constituencies; political actors disguised as nonpartisan civic actors; or unrepresentative elite actors. The report recommends that CSOs assess and where needed, strengthen their legitimacy and accountability. INGOs can support such processes by helping local CSOs diversify their funding and reduce their financial dependence on international donors.

As outlined in this paper, Oxfam has sought to strengthen its legitimacy and accountability in recent years by shifting more power and resources to the South and supporting Southern-led local and national change; developing and implementing partnership principles; and strengthening its reporting, feedback, and complaints mechanisms. In response to the 2018 safeguarding crisis, Oxfam is working to strengthen its safeguarding practices, feedback and complaints mechanisms, build a culture of zero tolerance to abuse and exploitation, and reform internal cultures and practices. It has also reinvigorated efforts to strengthen the alignment between its external influencing goals and values and internal values and cultures.

Looking forward, other ways of strengthening its accountability might include increasing independent oversight at different levels and strengthening downward accountability to the people Oxfam works with: for example by strengthening community feedback mechanisms, regular feedback, surveys, or by managers conducting $360^{\circ}$ reviews of key individuals and organizations (Lawrence, 2018).

Yet knowing how best to strengthen accountability can be a complex business for multi-mandate INGOs, given their internal complexity and their multiple stakeholders around the world including the people they work with on the ground, implementing partner organizations, influencing allies, public donors, supporters, institutional donors, targets, staff and regulatory and standard bodies in different countries. Moreover, internal institutional pressures relating to growth, fundraising, brand visibility, donor dependence and reporting, corporate partnerships and funding can inadvertently constrain such efforts. (Edwards, 2005; Martin, 2018).

Organizationally, INGOs are increasingly influenced by private sector models and ways of working (both of the corporate and entrepreneurial varieties), which is more a function of the changing funding landscape than of the proven effectiveness of these approaches (Edwards, 2005). Declining official aid flows (Roche and Hewitt, 2013) and increased donor emphasis on short-term measurable results and 'value for money' push INGOs towards more business-like and quantifiable strategies.

Taken together, such pressures risk drawing INGOs away from their community base, constraining their radical edge or undermining the trust and good relationships needed for effective influencing. Additionally, while measuring results is not necessarily incompatible with influencing (e.g. see Green, 2015) and corporate models can include many positive features (not least, their flexibility and 'systems thinking'), such trends pose serious challenges to influencing approaches that are longer term, non-linear and not easily 'projectized' or 'attributable'. 


\section{FUTURE DIRECTIONS}

If the locus and subject of influencing continues to shift towards Southern governments and societies, what role remains for INGOs, most of which continue to be based in the North? Their historical position as intermediaries between (rich) Northerners and (poor) Southerners is increasingly challenged, as some donors give directly to domestic Southern-based NGOs, while some Northern contributors prefer to send money directly through online platforms such as Kiva and Give Directly (Roche \& Hewitt, 2013). Some Southern NGOs are diversifying their sources of funding away from INGOs, given the many restrictive laws passed by governments to limit foreign influence. Simply moving one's headquarters to, or establishing an affiliate in, a Southern country does not guarantee that INGOs are locally relevant, or that their funding, power and management structures necessarily shift accordingly (Campolina, 2015; Bah, 2016).

Rightly or wrongly, some domestic civil society groups are concerned that localizing INGOs will crowd them out, out-compete them for funding and hire their best staff (Aboum, 2015; Tujan, 2015; Wall, 2015). Given the reality that few INGOs will willingly shrink, many are likely to select compromise strategies balancing organizational growth with the search for local relevance and flexibility (Edwards, 2016). INGOs that are squeezed by declining funding, shrinking civic spaces in home and operational countries, and pushback from assertive local civil society actors may be tempted to retreat from an influencing agenda or contentious issues (Geppert, 2017).

\section{CURRENT RESPONSES}

One possible INGO response to these external and internal trends is to stay big and grow. For example, humanitarian researcher Hugo Slim predicted that, by 2030, a small number of large INGOs will control much of aid funding (Slim, 2013). Only by increasing in size, proponents argue, can INGOs hope to exert an effective countervailing power to powerful global business and elites and influence global challenges such as climate change and conflict (Action Against Hunger et al, 2017). According to Pascal Boniface, director of the French research centre Iris, 'in a time of rapid and far-reaching global change, the need for a global vision and a long-term approach has never been more evident' (quoted in McVeigh, 2017).

An alternative response is encapsulated in the metaphor attributed to development worker Chris Roche: 'You can't take a super-tanker white-water rafting' (Green, 2014). According to proponents of this view, INGOs should aim to become local by enmeshing themselves in the complex realities of national and sub-national contexts: 'elite advocacy is too thin and foreign aid is too blunt a weapon to influence deep-rooted social, political and economic forces that must be addressed through struggles between local institutions' (Edwards, 2016). Since such struggles are inherently political, the focus of civil society action would need to be on changing local power relations (Kelmstra, 2017).

A localized strategy would also be consistent with the 'Doing Development Differently' manifesto, ${ }^{20}$ with its focus on solving local problems, convening and brokering, coalition building, and blending design and implementation through rapid cycles of feedback and adaptation. For INGOs, such an approach may imply reducing scale and control by giving up large-scale programme funding from donors in favour of supporting local CSOs, spin-offs and start-ups, and becoming agents of disruption and innovation (Green, 2015; Lawrence, 2018) or focussing on fewer things (Lawrence, 2018). This would not necessarily reduce an organization's impact, as influence is derived as much from the effective use of soft power and strategy as from hard power linked to size and resources (Braithwaite, 2004). As a popular meme now has it, 'the next big thing will be a lot of small things' (Maneshwari, 2016). 
Another related option, currently being pursued by Oxfam through its Worldwide Influencing Network, is for INGOs to act as global influencing networks that can more agilely support multilevel influencing in response to partners' and allies' needs. The role of INGOs in this approach is to help build power from below and to catalyze and link local, national, regional and international efforts to 'create a powerful movement demanding change' (Campolina, 2015).

\section{CHANNELLING THE LONG WAVES OF CHANGE}

Playing a connecting role, going local and being partner-led are all important. Yet the nature of systemic challenges, the power of multinational companies and financial elites and rising chauvinism, means that global and Northern influencing is still urgently needed. If progressive INGOs step back entirely from doing their own direct influencing in these arenas, the space they leave may be filled by other less progressive actors. Some Southern-based and international civil society allies interviewed for this paper want and expect Oxfam to both support Southern partners' efforts to achieve change (both at national and/or international level), and also to act powerfully in their own name. Further, while influencing through distributed networks may help to achieve change on some issues it may not be so effective for addressing structural or global issues which require focussed, coordinated and sustained action over the long term. Distributed networks can also involve cumbersome decision-making processes and make it more difficult for INGOs to ensure compliance with complex regulatory and ethical requirements (Lawrence, 2018).

Linked to this, care is needed not to inadvertently jettison INGOs established strengths. For example, Oxfam's multi-mandate mission and history of tackling the long-term structural causes of poverty have generated a set of influencing competences that are as important as ever. These include its global reach and relationships; its ability to catalyze international solidarity; its holistic multi-level and multi-pronged influencing capacities and strategies; and its ability to make visible the human impacts of macro policies, among others.

Political science and history show us that macro pressures, sudden events and crises offer opportunities for structural change as they exert pressure on dominant policies, practices and behaviours and open the door for niche innovations to spread (Geels \& Schot, 2007; Green, 2017). It also shows that legislative change, a key element of wider system change, is most likely to come about when three different political streams converge: political recognition of a problem, the presentation of mature policy solutions that conform to policy makers' values, and a conducive political environment including changes to public opinion and advocacy campaigns (Kingdon, 2003).

Viewed through this lens, the unfolding external crises linked to inequality, climate change and patriarchy, the widespread public disenchantment with dominant economic policy (Edelman, 2017) and growing political recognition of these problems suggest that a more politically conducive climate for change is emerging. This in turn offers I/NGOs and civil society a critical opportunity to help channel public disenchantment with dominant neoliberal economic policies towards more humane, just and sustainable approaches.

Successfully doing so will require the agile use of many time-tested change strategies developed by NGOs and the social justice movement over decades, including strategies to counter vested interests and their ideologies. But the rise of chauvinism and far-right populism also highlights the urgent need for new influencing approaches and strategies. 


\section{A SHARED VISION AND JOINT ACTION TO TACKLE KEY STRUCTURAL CAUSES OF POVERTY}

One criticism of I/NGOs is their difficulty in cooperating for their greater shared purpose, due to a focus on individual brand promotion and a multitude of seemingly unrelated single-issue messages and campaigns. As such, they sometimes do not present to their societies as a broad movement for a fairer and more sustainable society, but more as competing voices on myriad single-issue campaigns, fire-fighting symptoms rather than addressing structural causes, and with no explicit or discernible shared vision. In these dangerous times, such competition cannot be afforded. Thus, a critically important future direction for INGOs would be to:

- Coalesce around a positive shared vision, focus and narrative aimed at creating a fairer, more inclusive and sustainable world. This will require much closer and longer term cooperation with and between domestic and international development, human rights, labour, environment, single issue and identity movements than has been seen so far, as well as with non-traditional allies;

- Devote a proportion of institutional resources to collectively prioritizing and addressing key structural causes of poverty, for example relating to corporate regulation (or lack of), "power imbalances or state capture by vested interests. For example, one key underlying cause of the many social and environmental problems is a business and financial regulatory system that prioritizes short-term financial returns to shareholders over and above social and environmental issues. (Haldane, 2015). This will require greater use of multi-level, multi-pronged influencing strategies to tackle visible, invisible and hidden power.

\section{BROADENING ENGAGEMENT AND STRENGTHENING CIVIL SOCIETY VOICE}

To effectively address the structural causes of poverty and systemic challenges, INGOs will need to appeal to and motivate a majority of society, rather than just existing active supporters. Some INGOs' communication messages still emphasize their life-saving work or efforts to help the poorest $5-10 \%$ and the most vulnerable sections of the population. This remains of fundamental importance, as does the role of INGOs in highlighting the historic and ongoing links between policies in rich countries and poverty in the Global South.

However, particularly since the financial crash in 2008, the experience of large proportions of societies in both the North and South has increasingly been one of precarious employment, stagnant wages, and the withdrawal of essential services through austerity and environmental destruction. INGOs could help build a powerful constituency for change in both the South and North, while still being consistent with their missions, if they could:

- Broaden their communication messages and engagement and influencing strategies to highlight and address the problems faced by much wide sections of society affected by precarious employment, stagnant wages, the withdrawal of essential services and environmental destruction in both the South and North - as well as the plight of the most vulnerable. The slowness of some INGOs to widen communications and engagement has arguably helped to leave the field open to chauvinist and populist messages;

- Balance critiques with increased effort and investment to identify, promote and communicate structural solutions that will benefit wider sections of society. As well as supporting iterative shared learning processes to develop and test solutions, INGOs will also need to pre-package and stand ready to hook identified solutions to windows of opportunities when they emerge;

- Increase their support for and investment in the long-term processes needed to cultivate active citizens and build social movements in the North as well as the South (including upstream investment in development education for young people), rather than simply mobilizing people to support pre-defined branded campaigns. Doing so effectively will entail working closely with 
partners to blend both creative new online methods with participatory face-to-face offline methods and investment in training and mentoring;

- Work with donors to increase understanding of the valuable poverty-reduction roles of informal grassroots associations, women's rights organizations and social movements in tackling poverty and injustice, and to develop more agile funding and reporting systems to support them (while taking care not to impose agendas or inadvertently co-opt them);

- Spend more time directly and actively listening to, learning from and finding common ground and shared solutions with more diverse publics, individuals and organizations.

- Continue to strengthen legitimacy, accountability and internal cultures and practices, as important goals in their own right and to ensure their social mandate to operate.

\section{CONCLUSIONS}

This paper has examined why and how Oxfam's influencing has evolved, and continues to evolve, in response to changing contexts and learning from partners, allies and others. It has shown the important role influencing can play, alongside practical and material assistance, in helping to strengthen the voices of marginalized groups and achieve a fairer and more sustainable world. But it also argues that there is an urgent need for INGOs and wider civil society to renew and strengthen their influencing strategies in the light of the profound development challenges and disruptive change the world faces. Critically, the paper highlights the need for INGOs to act collectively, effectively and decisively as part of broad alliances to prioritise and tackle key structural causes of poverty and injustice and to help channel the current wave of public disenchantment towards humane, just and sustainable solutions. If they, don't others will inevitably do so in chauvinist and authoritarian directions. 


\section{REFERENCES}

All links last accessed November 2018, except where specified.

Aboum, A. (2015) INGOs in Africa. D+C, Accessed May 16, 2017.

ActionAid. History. Retrieved from http://www.actionaid.org/who-we-are/history

Action Against Hunger (2017). The Future of Aid INGOs in 2030. IARAN. http://iaran.org/futureofaid/\#introstatement

Bah, V. (2016). Will the Sky Fall When Big NGOs Move South? https://www.opendemocracy.net/5050/will-skyfall-when-big-ngos-move-south.

Bailey, M., Mayne, R., and Kamal, M. (2001). Fatal Side Effects: Medicines patents under the microscope. Oxfam GB. https://policy-practice.oxfam.org.uk/publications/fatal-side-effects-medicine-patents-under-themicroscope-112551

Banks, N. and Hulme, D. (2012). The Role of NGOs and Civil Society in Development and Poverty Reduction, Brooks World Poverty Institute Working Paper No. 171. 1 June 12012.

Bennet, F, with Thorgeirsson, S., Barzelay, A. and Brookes, R. (2018). Shared Space Under Pressure: Business support for civic freedoms and human rights defenders. Business and Human Rights Resource Centre, International Service for Human Rights.

Beardon, H. and Otero, E. (2013). Women's Right to be Heard: An evaluation of Oxfam GB's 'Raising her Voice' portfolio. Evaluation Report. Leitmotiv. https://policy-practice.oxfam.org.uk/publications/womens-rightto-be-heard-an-evaluation-of-oxfam-gbs-raising-her-voice-portfolio-301544

Birdsall, N., Rodrik, D. and Subramanian, A. (2005). How to Help Poor Countries. Foreign Affairs. July/August 20015.

Black, M. (1992). A Cause for Our Times: Oxfam the first 50 years. Oxfam GB. https://policypractice.oxfam.org.uk/publications/a-cause-for-our-times-oxfam-the-first-50-years-123014

Braithwaite, J. and Drahos, P. (2000). Global Business Regulation. Cambridge University Press.

Braithwaite and Drahos, (2002). Zero Tolerance: Naming and shaming: Is there a case for it with crimes of the powerful? ANU. The Australian and New Zealand Journal of Criminology. 269, 35:3.

Braithwaite (2004). Methods of Power for Development: Weapons of the weak, weapons of the strong. Michigan Journal of International Law.

Brechenmacher, S. and Carothers, T. (2018). Examining Civil Society Legitimacy. Carnegie Endowment for International Peace.

Brook, S., et al. (2015, August). Advocacy and the Politics of Policy-Making: The coalition support programme in Vietnam. Oxford Policy Management.

Brown, G. eds. (2016). The Universal Declaration of Human Rights in the 21st Century: A Living Document in a Changing World. Open Book Publishers. doi:10.11647/OBP.0091.

Cairney P. (2018). Three Habits of Successful Policy Entrepreneurs. Policy \& Politics. 46 (2):199-217.

DOI: https://doi.org/10.1332/030557318X15230056771696

Campolina, A. (2017). Facilitating More Than Leading. D+C. https://www.dandc.eu/en/article/why-actionaidhad-move-its-headquarters-britain-south-africa.

CARE. (n.d.) CARE's History. https://www.care-international.org/who-we-are/cares-history

Carter, B., Joshi, A. and Remme, M. (2018). Scaling Up Inclusive Approaches for Marginalised and Vulnerable People. K4D. University of Sussex, Institute of Development Studies.

Castells, M. (1996). The Rise of the Network Society. Wiley-Blackwell.

Channon, A. and Ngulube, E. (2015). I Care About Her: Building a movement of champions in Zambia to end violence against women and girls. Oxfam. https://policy-practice.oxfam.org.uk/publications/i-care-about-her- 
building-a-movement-of-champions-in-zambia-to-end-violence-aga-345992

Christie, K. and Coe, J. (2014). Review of Advocacy in INGO Peer Organisations. A report for CARE 2014. (Internal paper).

Clarke, J. (1985). For Richer For Poorer: An Oxfam report on western connections with world hunger. Oxfam GB. https://policy-practice.oxfam.org.uk/publications/for-richer-for-poorer-an-oxfam-report-on-westernconnections-with-world-hunger-121191

Clarke, J. (1991). Democratising Development. Development in Practice. 2:3. pp1510162 Taylor and Francis on behalf of Oxfam GB.

Cootes, B. and LeQuesne, C. (1992). The Trade Trap. Oxfam GB. https://policypractice.oxfam.org.uk/publications/the-trade-trap-123049

Cornea, G., Jolly, R. and Stewart, F. (1987). Adjustment with a Human Face. Oxford: Oxford University Press.

Cousins, S., Kirsten, H. and Ellie, K. (2015). A Rights in Crisis Guide to Influencing: The who, what and why of humanitarian campaigning. Oxfam International. https://policy-practice.oxfam.org.uk/publications/a-rights-incrisis-guide-to-influencing-the-who-what-and-why-of-humanitarian-ca-583068

Crowson, N., Hilton, M., McKay, J., eds (2009). NGOs in Contemporary Britain: Non-state actors in society and politics since 1945. Palgrave MacMillan. DOI: 10.1057/9780230234079

https://www.palgrave.com/gb/book/9780230221093

Dany, C., and Schneiker, A. (2015). Experts, Advocates, and Activists. Development and Cooperation. https://www.dandc.eu/en/article/international-ngos-play-various-roles-global-politics-their-scope-influencevaries-do-their.

Economist (2018). Economist May Help to Revive Organised Labour. The Economist. Print edition. Briefing. 15 November 2018.

Edleman (2017 and 2018). Trust Barometers. online survey in 28 countries. https://www.edelman.com/research/2017-edelman-trust-barometer https://www.edelman.com/trust-barometer

Edwards, M. (2005). Have NGOs 'Made a Difference'? From Manchester to Birmingham with an elephant in the room. Global Poverty Research Group, ESRC. http://www.gprg.org/pubs/workingpapers/pdfs/gprg-wps028.pdf

Edwards, M. (2014). Civil Society. $3^{\text {rd }}$ edition. Cambridge: Polity Press.

Edwards, M. (2016). What's to be done with Oxfam? Blog. Open Democracy.

https://www.opendemocracy.net/transformation/michael-edwards/what-s-to-be-done-with-oxfam.

Fooks, L. (2018). Making Policy Care: A Guide to influencing on unpaid care. Oxfam. https://policypractice.oxfam.org.uk/publications/making-policy-care-a-guide-to-influencing-on-unpaid-care-620563

Foresti, M. and Ludi, E. (2007). Human Rights and Livelihood Approaches for Poverty Reduction, ODI. https://www.odi.org/sites/odi.org.uk/files/odi-assets/publications-opinion-files/2297.pdf.

Galasso, N, Feroci, G. Pfeifer, K., Walsh, M. (2017). The Rise of Populism and its Implications for Development NGOs. Research Backgrounder. Oxfam America.

Gaventa, J. (2009). Finding the Spaces for Change: A power analysis. IDS Bulletin. 37:6. University of Sussex. Institute of Development Studies. https://onlinelibrary.wiley.com/doi/full/10.1111/j.17595436.2006.tb00320.x

Gemmill, B. and Bamidele-Izu, A. (2002). The Role of NGOs and Civil Society in Global Environmental Governance. In: Global Environmental Governance: Options and Opportunities. 2002, 77-100.

Yale. http://environment.yale.edu/publication-series/782.html

Geels, F.W. (2002). Technological Transitions as Evolutionary Reconfiguration Processes: A multi-level perspective and a case study. Research Policy $31 \mathrm{pp} .1257-1273$.

Geels, F.W. and Schot, J. (2007). Typology of Sociotechnical Transition Pathways. Research Policy. 36 (2007). 399-417. Science Direct, Elsevier. 
George, S. (1990). A Fate Worse than Debt. New York: Grove Widenfeld.

Geppert, M. (2017). Making Democratic Principles Tangible. D\&C. https://www.dandc.eu/en/article/shrinkingspaces-call-new-support-strategies.

Girvan, N. (2007) Power Imbalances and Development Knowledge. Citeseer. http://citeseerx.ist.psu.edu/viewdoc/download?doi=10.1.1.370.1497\&rep=rep1\&type=pdf

Global Exchange. (2017). Celebrating 30 Years of Activism for Human Rights. https://globalexchange.org/about-us/our-successes/

Goodrich, I. (2017). From Service Delivery to Sustainable Water Management in Tajikistan. Oxfam. https://oxfamilibrary.openrepository.com/bitstream/handle/10546/620294/cs-from-service-delivery-tajikistan100717-en.pdf?sequence $=4$

Gready, P. (2008). Rights-Based Approaches to Development: What is the value-added? Development in Practice 18:6. 735-47. doi:10.1080/09614520802386454

Green, D. (2011). From Poverty to Power: How active citizens and effective states can change the world. $2^{\text {nd }}$ edition. Practical Action Publishing and Oxfam International. https://policy-

practice.oxfam.org.uk/publications/from-poverty-to-power-2nd-edition-how-active-citizens-and-effective-statescan-249411

Green, D. (2014). You Can't Take a Supertanker White-Water Rafting: What future for international NGOs? From Poverty to Power blog, 10 December 2014. http://oxfamblogs.org/fp2p/you-cant-take-a-supertankerwhite-water-rafting-what-future-for-international-ngos/.

Green, D. and MacDonald, A. (2015). Power and Change: The Arms Trade Treaty. Oxfam case study. Oxfam. https://policy-practice.oxfam.org.uk/publications/power-and-change-the-arms-trade-treaty-338471

Green, D. (2016). How Change Happens. Oxford University Press.

Green, D. (2017). Fit for the Future? Development Trends and the Role of NGOs. Oxfam. https://policypractice.oxfam.org.uk/publications/fit-for-the-future-development-trends-and-the-role-of-international-ngos556585

Groves, L. C., and Hinton, R. B. (2013). Inclusive Aid: Changing power and relationships in international development. Earthscan.

Haldane, A. (2015). Who Owns a Company? Speech by Andrew G. Haldane, Executive Director and Chief Economist of the Bank of England, at the University of Edinburgh Corporate Finance Conference, Edinburgh, 22 May 2015.

Hamilton, J., Mayne, R., Parag, Yael and Bergman, N. (2015) Scaling up local carbon action: the role of partnerships, networks and policy, Carbon Management, DOI: 10.1080/17583004.2015.1035515

Hamilton, S. (2006). Rights-Based Approaches to Development.

http://www.du.edu/korbel/hrhw/researchdigest/development/development.pdf.

Hardoon, D. (2017). An Economy for the 99\%: It's time to build a human economy that benefits everyone, not just the privileged few. Oxfam. https://oxf.am/2sozLKI

Timms, H. and Heimans, J. (2018). New Power. Doubleday Publications.

Hoeidrup, S. (2015). Influencing for Impact: A guide and toolkit for influencing, advocacy and campaigning in Oxfam. Oxfam (internal document).

Htun, M. and Weldon, S.L. (2012). The Civic Origins of Progressive Policy Change: Combatting violence against women in global perspective, 1975-2005. American Political Science Review. 106:3.

International Centre for Not-for-profit Law (2016). Global Trends in NGO Law. Vol. 7, no. 4, 2016.

http://www.icnl.org/research/trends/trends7-4.pdf?pdf=trends7-4.

International Labour Organization (1995). World Employment Report. Geneva: ILO.

http://www.ilo.org/global/publications/ilo-bookstore/order-online/books/WCMS_PUBL_9221094480_EN/lang-en/index.htm

International Labour Organization (1996). World Employment Reports1995. Geneva: ILO. 
http://www.ilo.org/global/publications/ilo-bookstore/order-online/books/WCMS_PUBL_9221094480_EN/lang-en/index.htm

Jayawickrama, S. and Ebrahim, A. (2013). Building and Governing a Democratic Federation: The ActionAid International Story. The Hauser Center for Non-Profit Organizations, Harvard University.

http://www.actionaid.org/sites/files/actionaid/building_and_governing_a_democratic_federation_20june2013__copie.pdf

Jubilee Debt Campaign (undated). What We Do. Website. Retrieved from https://jubileedebt.org.uk/about-us

Kelmstra, J. (2017). Dialogue and Dissent Theory of Change 2.0: Supporting civil society's political role. Netherlands Ministry of Foreign Affairs, July 2017.

Kemp, R., Schot, J. and Hoogma R. (1998). Regime Shifts to Sustainability Through Processes of Niche Formation: The approach of strategic niche management. Technol. Anal. Strateg. Manag. 10:2. 175-195.

Keystone (2014). Partner Feedback Report: Oxfam. Keystone Performance Surveys.

https://www.oxfam.org/sites/www.oxfam.org/files/file_attachments/story/oxfampartnerfeedbackreport05sept20 14.pdf

Korten, D. (1987). Third Generation NGO Strategies: A Key to people-centred development. World Development. Vol. 15, Supplement, pp. 145-159.

Kumar, A. and Messner, D. (2011). Power Shifts and Global Governance: Challenges from South and North. Anthem Press.

Kingdon, J. (2003). Agendas, Alternatives and Public Policies, 2nd Edition. Longman.

Lam, N.T. (2017). Even It Up: How to tackle inequality in Vietnam. Oxfam. https://policypractice.oxfam.org.uk/publications/even-it-up-how-to-tackle-inequality-in-vietnam-620171

Lawrence, P. (2018). Whither Large International Non-Governmental Organisations? Third Sector Research Centre. Plowden Fellowship Report, University of Birmingham, ESRC.

La Via Campesina website. https://viacampesina.org/en/

Lejeune, A. and Winder, Y. (2016, July 20). Do Aid Organisations Need Marriage Guidance? Five lessons for better partnerships. From Poverty to Power blog. https://oxfamblogs.org/fp2p/do-aid-organisations-needmarriage-guidance-five-lessons-for-better-partnerships/

Lombardini, S. (2017). Using Internal Evaluations to Measure Organizational Impact: Findings from a metaanalysis of women's empowerment projects. Oxfam. https://policy-practice.oxfam.org.uk/publications/usinginternal-evaluations-to-measure-organizational-impact-a-meta-analysis-of-620348

Lockwood, M. (2006). The State They're In: An agenda for international action on poverty in Africa. Practical Action Publishing.

Lukes, S. (2005). Power: A Radical View. 2nd Edition. London: Palgrave.

Maduraiveeran. P. and Muthuramalingam, T. (2017). Role of NGOs in Realizing Millennium Development Goals: A study in Tamil Nadu, India. Accessed 26 June 2017. http://paperroom.ipsa.org/papers/paper_36867.pdf.

Maes, J. (2016). From Grove to Market: Oxfam's multi-stakeholder approach in the West Bank. Oxfam Case Study. https://policy-practice.oxfam.org.uk/publications/from-grove-to-market-oxfams-multi-stakeholdernetwork-approach-in-the-west-bank-620118

Makoba, W.J. (2002). Nongovernmental Organizations (NGOS) and Third World Development: An alternative approach to development. Global Policy Forum. Accessed 18 May 2017. https://www.globalpolicy.org/component/content/article/177/31620.html.

Maneshwari, L. (2016). The Next Big Thing Is a Series of Small Things. Blog. Huffington Post. 1 May 12016. http://www.huffingtonpost.com/st-gallen-symposium/the-next-big-thing-is-a-s_b_7178652.html.

Marshall, D. and Sterparn, J. (2012). Oxfam Aid to Canada's First Nations, 1962-1975: Eating lynx, starving for jobs, and flying a talking bird. Journal of the Canadian Historical Association. , 23:2. p. 298-343.

Martin, P. (2018). Reimagining Our Organisations. Blog. Civicus. https://www.civicus.org/index.php/re- 
imagining-democracy/overviews/3328-reimagining-our-organisations

Mayne R. (2002). The Global Campaign on Patents and Access to Medicines: An Oxfam perspective. In: Drahos P., Mayne R. (eds) Global Intellectual Property Rights. London: Palgrave Macmillan.

Mayne, R., Kesmaecker-Wissing, Knight, L. and Miziniak. J. (2018). Influencing Behaviours and Practices to Tackle Poverty and Injustice. Oxfam Discussion Paper, Oxfam. https://policypractice.oxfam.org.uk/publications/influencing-behaviours-and-practices-to-tackle-poverty-and-injustice620407

Mayne, R., Green, D., Guijt,I., Walsh, M. and Cairney,P. (2018). Using Evidence to Influence Policy: Oxfam's experience. Palgrave Communications.

McGann, J. and Johnstone, M. (2006). The Power Shift and the NGO Credibility Crisis. International Journal of Not-for-Profit Law. January 2006. Accessed May 18, 2017.

https://www.globalpolicy.org/component/content/article/176/31423.html.

McVeigh, K. (2017). 'Change or Die': Aid charities told to stop competing for funds or face extinction. The Guardian. 20 July 2017. https://www.theguardian.com/global-development/2017/jul/20/change-or-die-aidcharities-told-to-stopcompeting-for-funds-or-face-extinction.

Mhlanga,R., Gneiting, W. and Namit, A. (2018). Walking the Talk: Assessing companies' progress from SDG rhetoric to action. Oxfam. https://policy-practice.oxfam.org.uk/publications/walking-the-talk-assessingcompanies-progress-from-sdg-rhetoric-to-action-620550

Michaela, R. (2011). The We Can Campaign in South Asia, 2004-2011: External evaluation report. Oxfam. https://policy-practice.oxfam.org.uk/publications/the-we-can-campaign-in-south-asia-2004-2011-externalevaluation-report-146189

Molina-Gallart, N. (2014). Strange Bedfellows? NGO-corporate Relations in International Development: An NGO perspective. Development Studies Research 1, no. 1 (1 January 2014): 42-53.

doi:10.1080/21665095.2014.915617.

Moorhead, J., and Clarke, J.S (2015). Big NGOs Prepare to Move South, But Will it Make a Difference? The Guardian. 16 November 2015. https://www.theguardian.com/global-development-professionalsnetwork/2015/nov/16/big-ngos-africa-amnesty-oxfam-actionaid?CMP=share_btn_tw.

Morchain, D. (2016, 6 May). The Challenge of Climate Change Adaptation in the Philippines. Blog. Oxfam. https://policy-practice.oxfam.org.uk/blog/2016/05/climate-change-adaptation-in-the-philippines

Moyo, D. (2009). Dead Aid: Why aid is not working and how there is another way for Africa. Penguin.

Nyamu-Musembi, C., and Cornwall, A. (2004). What Is The 'Rights-Based Approach' All About? Perspectives from international development agencies. https://opendocs.ids.ac.uk/opendocs/handle/123456789/4073.

Offenheiser, R. C., and Holcombe, S.H. (2003). Challenges and Opportunities in Implementing a RightsBased Approach to Development. Oxfam America.

Osman, F. A. (2002). Public Policy Making: Theories and their implications in developing countries. Asian Affairs 24:3 37-52.

Oxfam (1995). A Case for Reform: 50 years of the IMF and WB. Oxfam GB. https://policypractice.oxfam.org.uk/publications/a-case-for-reform-fifty-years-of-the-imf-and-world-bank-115386

Oxfam (2012). Working together: Oxfam's Partnership Principles. Oxfam. https://www.oxfam.org/sites/www.oxfam.org/files/oxfam-partnership-principles.pdf

Oxfam (2013). The Power of the People against Poverty: Oxfam Strategic Plan, 2013-19. https://www.oxfam.org/en/countries/oxfam-strategic-plan-2013-2019-power-people-against-poverty

Oxfam (2016a). Enough is Enough: Oxfam seeks to end violence against women and girls once and for all. Press release. https://www.oxfam.org/en/pressroom/pressreleases/2016-11-24/enough-enough-oxfam-seeksend-violence-against-women-and-girls

Oxfam (2016b). Oxfam Accountability Report, 2015-16. Oxfam. 
Oxfam (2016c). Putting Oxfam's Partnership Principles into Practice, Oxfam's partnership toolkit: Minimum standards and good practice. Oxfam. https://policy-practice.oxfam.org.uk/publications/putting-oxfamspartnership-principles-into-practice-611581

Oxfam (2017a). Oxfam Influencing Strategy on Shrinking and Shifting Civic Space. Internal document.

Oxfam (2017b), Oxfam Private Sector Framework, Policies and Procedures. Internal document.

Oxfam (2018a). Safeguarding in Action: Our 10-Point Plan. Online report. Oxfam.

https://www.oxfam.org/en/oxfams-commitment-stamping-out-sexual-harassment-and-abuse

Oxfam (2018b). Oxfam in the Philippines Annual Report. Oxfam.

Oxfam (2018c). Influencing Achievements, Stories of Change. Internal case study. Oxfam.

Oxfam (2018d). Oxfam internal evaluation of the Actua,pe Inequality Labs. Internal report. Oxfam.

Oxfam. Mum's Magic Hands. Online resources. Retrieved from. https://policy-practice.oxfam.org.uk/ourwork/water-sanitation-and-hygiene/mums-magic-hands

Oxfam. History of Oxfam International. Retrieved from https://www.oxfam.org/en/countries/history-oxfaminternational

Oxfam. Zero Hunger - Zero Emissions. Retrieved from https://policy-practice.oxfam.org.uk/our-work/foodlivelihoods/zero-hunger-zero-emissions

Oxfam. National Influencing Guidelines. Internal document (work in progress).

Oxfam (undated). Four Simple Strategies Which are Helping Ethiopian Farmers Adapt to Climate Change. Retrieved from https://www.oxfam.org/en/ethiopia/four-simple-strategies-which-are-helping-ethiopian-farmersadapt-climate-change

Panke, D. and Henneberg, I. (2017). International Organizations and Foreign Policy. Oxford Research Encyclopaedia, Politics. Accessed 18 May 2017. https://www.researchgate.net/publication/314366312_Internationa'I_Organizations_and_Foreign_Policy.

Picciotto, S. and Mayne, R. (1999). Regulating International Business: Beyond Liberalisation. MacMillan and Oxfam GB.

Purushothaman, C. (2014). Foreign Aid and South-South Cooperation: Emerging powers as donors. Centre for International Politics, Organisation and Disarmament. Jawaharlal Nehru University, New Delhi. http://web.isanet.org/Web/Conferences/FLACSO-ISA\%20BuenosAires\%202014/Archive/fb22e0c3-90e34649-87e7-d3de70049593.pdf

Rao, A. and Kelleher, D. (2010). Is There Life after Gender Mainstreaming? Gender \& Development 13:2 5769

Raworth, K. (2017). Doughnut Economics: Seven Ways to Think like a $21^{\text {st }}$ Century Economist. Penguin.

Raising Her Voice. (2011). Defending women's rights in Honduras. Blog. https://www.oxfamblogs.org/lac/wpcontent/uploads/2011/09/RaisingHerVoice_Honduras.pdf

Reimann, K. D. (2006). A View from the Top: International Politics, Norms and the Worldwide Growth of NGOs. International Studies Quarterly. 50:1 45-67. doi:10.1111/j.1468-2478.2006.00392.x.

Rifkin, J. (2014). The Zero Marginal Cost Society. MacMillan.

Roche, C. and Hewett, A. (2013). The End of the Golden Age of International NGOs? Paper presented at the ACFID/University Linkage Conference, 21-22 November 2013.

Rodriguez, T.D. (2016). Lessons Learned from Supporting the Development of a Network of Networks for Advocacy in the Global South. Oxfam. https://policy-practice.oxfam.org.uk/publications/lessons-learned-fromsupporting-the-development-of-a-network-of-networks-for-ad-610883

Rodriguez. T. D. (2018). What's the Role for Oxfam in Supporting Social Movements for Change? Blog. https://views-voices.oxfam.org.uk/governance/land-rights/2018/06/whats-the-role-of-oxfam-in-supportingsocial-movements-for-change

Roodman, D. (2010). The Arc of the Jubilee. Center for Global Development. 
http://cgdev.org.488elwb02.blackmesh.com/publication/arc-jubilee

Rowlands, J. (1997). Questioning Empowerment. Oxfam GB. https://policy-

practice.oxfam.org.uk/publications/questioning-empowerment-working-with-women-in-honduras-121185

Rowlands, J. (2016). Power in Practice: Bringing Understandings and Analysis of Power into Development Action in Oxfam. IDS Bulletin 47:5 (2016).

http://bulletin.ids.ac.uk/idsbo/article/view/2796/ONLINE\%20ARTICLE

Sahan, E. (2016). The Journey to Sustainable Food: A three year update on the Behind the Brands Campaign. Oxfam. https://www.oxfam.org/sites/www.oxfam.org/files/file_attachments/bp-journey-tosustainable-food-btb-190416-

Sanchez, de Ocana and Lenton, A. (2018). Learning from the Evaluations of Oxfam's Work in Latin America and the Caribbean. Oxfam.

Save the Children. Our Story. Online article. Retrieved from https://www.savethechildren.net/about-us/ourstory

Schlangen, R. and Coe, J. (2014). The Value Iceberg: Weighing the benefits of advocacy and campaigning. Better Evaluation.

http://www.betterevaluation.org/sites/default/files/Advocacy\%20and\%20the\%20value\%20iceberg.pdf

Sidel, J. (2015). Coalition Support Program (CSP): Independent End-Term Review. Oxfam.

Siesfeld, T., Cefola, J. and Neef, D. (2009). The Economic Impact of Knowledge. Routledge.

Sikkink, K. (2015). Latin America's Protagonist Role in Human Rights, International Journal on Human Rights. No.22.

Shephard, D., Meuer, J., Ellersiek, A., and Rupietta, C. (2018). Influencing Policy and Civic Space: A metareview of Oxfam's policy influence, citizens voice and governance. Oxfam Effectiveness Reviews. Oxfam GB. https://policy-practice.oxfam.org.uk/publications/influencing-policy-and-civic-space-a-meta-review-of-oxfamspolicy-influence-cit-620462

Slim, H. (2013). NGOs and the Future: A Think Piece. Australian Council for International Development. www.acfid.asn.au/learning-development/files/ngos-and-the-future-a-think-piece/view

Smith, . and Seyfang, G. (2013). Constructing Grassroots Innovations for Sustainability. Glob. Environ. Change 23(5), 827-829.

Stamatopoulou, E. (1998). The Importance of the Universal Declaration of Human Rights in the Past and Future of the United Nation's Human Rights Efforts. ILSA J. Int'I \& Comp. L. 5 (1998): 281.

Sternin, J., Sternin, M. and Pascale, R. (2010. The Power of Positive Deviance: How unlikely innovators solve the world's toughest problems. Harvard Business Press.

Thekkudan, J., Menon, R. and Thomas.M. (2016). Understanding Social Norms Underpinning Domestic Violence in India. Oxfam India.

Tujan, A. (2015). Unequal partners. D+C. Accessed 16 May 2017. https://www.dandc.eu/en/article/ingos-arenorthern-based-agencies-claiming-speak-marginalised-people-global-south.

United Nations (2015). World Humanitarian Summit Secretariat, Restoring Humanity: Synthesis of the Consultation Process for the World Humanitarian Summit, UN, New York. https://consultations.worldhumanitariansummit.org/bitcache/32aeda5fe90ceba891060ad51d0bd823da273cf9? vid=555986\&disposition=inline\&op=view

UNAIDs (2011) Data Tables, www.unaids.org/sites/default/files/media_asset/JC2225_UNAIDS_datatables_en_1.pdf

Van Stekelenburg, J., Klandermans, B., and Akkerman, A. (2016). Does Civic Participation Stimulate Political Activity? Journal of Social Issues. 72:2 286-314.

van Hemelrijck, A. (2017). Governance in Myanmar: Evaluation of the 'Building equitable and resilient livelihoods in the Dry Zone' project. Oxford: Oxfam GB. 
Valerie, B. (2016). Will the Sky Fall When Big NGOs Move South? OpenDemocracy https://www.opendemocracy.net/5050/will-sky-fall-when-big-ngos-move-south.

Walker, M., and Christie, K. (2015). Where Change Happens: How International NGOs Are Shifting the Focus of Their Advocacy \& Campaigning towards the Global South. 15 http://edenstanley.co.uk/wpcontent/uploads/2015/07/Where-Change-Happens-Eden-Stanley-WebVersion-July-2015.pdf.

Wall, I. (2015). Gloves Off Between Local and International NGOs. IRIN. 22October 2015. http://www.irinnews.org/analysis/2015/10/22.

Watkins, K. and Fowler, P. (2002). Rigged Rules and Double Standards: Trade, Globalisation and the Fight against Poverty. Oxfam International. https://policy-practice.oxfam.org.uk/publications/rigged-rules-anddouble-standards-trade-globalisation-and-the-fight-against-pov-112391

World Social Forum. Website. https://wsf2018.org/en/

Youngwan, K. (2011). The Unveiled Power of NGOs: How NGOs Influence States. Foreign Policy Behaviors. 2011. http://ir.uiowa.edu/etd/1153/.

Youngs, R. (eds). (2017). Global Civic Activism in Flux. Washington: Carnegie Endowment for International Peace. 
1 'Oxfam' refers to the entire Oxfam International confederation unless otherwise stated. When relevant, the names of individual affiliates are given.

2 We recognize the inadequacy and increasing inaccuracy of the terms 'South' and 'North', but use them here as shorthand. By 'North' we mean richer countries such as the United States, Canada, Europe, developed parts of Asia (Hong Kong, Singapore, South Korea and Taiwan) as well as Australia and New Zealand. By 'South' we mean lower income countries in Africa, Latin America, and other parts of Asia including the Middle East.

3 All strategies involve a role for research and evidence.

4 By 'INGO' we mean a multi-mandate, multi-country international non-government organization.

5 Hidden power is understood to be exercised by informal decision makers and 'influentials' who operate behind the scenes; and 'invisible power' to be exercised through cultural beliefs and social norms (Rowlands 1997; Lukes 2005; Gaventa 2009).

6 See https://policy-practice.oxfam.org.uk/our-work/gender-justice/ending-violence-against-women/we-can

7 See note 2 .

8 All strategies involve a role for research and evidence.

9 Oxfam affiliate organizations have different histories - see Box 6. However, due to constraints of the scope of this paper, we have not included them here.

10 The education programme worked with youth inside and outside the formal education system. Schools and teachers were seen as constituting a powerful set of key multipliers and a way of reaching the full diversity of the UK population in terms of ethnicity and social class. (Internal reports)

11 See https://en.wikipedia.org/wiki/Make_Poverty_History

12 See https://viacampesina.org/en/

13 See https://wsf2018.org/en/

14 https://www.tandfonline.com/doi/ref/10.1080/13668800120079045?scroll=top

https://www.theguardian.com/global-development/2018/feb/17/mexico-zapatistas-rebels-24-yearsmountain-strongholds

https://www.rand.org/content/dam/rand/pubs/monograph_reports/MR1382/MR1382.ch6.pdf

http://globalalternatives.org/files/MartinezTorresZapatistas.pdf

15 Oxfam works with many different types of partner organization and allies. It understands partnerships as mutually empowering relationships, which are aware of power imbalances and focused on mutual growth, organizational development, institutional strengthening and above all, on achieving impact. An alliance can be with a single organization or groups of organizations working together towards a specific goal, even though organizational/institutional mandates and long-term purpose may be quite different. Alliances are more likely to be based on shared influencing, advocacy or communications objectives, than funding relationships, although some funding may be entailed.

16 The report defined widening civic space as increasing access, use or expansion of political spaces within which CSOs can exert power and have their voices heard on policy topics.

17 https://en.wikipedia.org/wiki/Multilateral_Agreement_on_Investment

18 The meta-review defined 'widening civic space' as expanding political spaces within which CSOs and citizens can exert power and have their voices heard on policy topics, and 'changing policy' as bringing about change in the programmes, policies, procedures or budgets of the government.

19 For example, the demand for trans-Atlantic emigration prompted by the Irish potato famine, European political instability and the lure of gold in California promoted innovations in steamship development. From the late 1880s, the technology became more affordable as the technology improved and spread. This led to the creation of new management and practices, as well as supporting infrastructures and institutions (Geels, 2002).

20 See http://doingdevelopmentdifferently.com/. 


\section{Oxfam Discussion Papers}

Oxfam Discussion Papers are written to contribute to public debate and to invite feedback on development and humanitarian policy issues. They are 'work in progress' documents, and do not necessarily constitute final publications or reflect Oxfam policy positions. The views and recommendations expressed are those of the author and not necessarily those of Oxfam.

This paper was written by Ruth Mayne, Chris Stalker, Andrew Wells-Dang and Rodrigo Barahona, with contributions by Thomas Dunmore Rodriguez and Sally Golding. Oxfam would like to thank the following people who commented on or contributed to the paper: Abhijit Bhattacharjee, Alison Tate, Barbara Oosters, Celine Charvariat, Duncan Green, Ed Pomfret, Fenella Porter, Franc Cortada, Francesca Rhodes, Gopika Bashi, Irene Guijt, Isabel Crabtree-Condor, Jacky Repila, Jamie Atienza, John Clarke, John Magrath, Kalayaan Constantino, John Magrath, Julie Delahanty, Julie Thekkudan, Maggie Black, Martin Khor, Matthew Spencer, Michael Borum, Ode Lundardi, Pauline Martin, Patricia Miranda, Raquel Checa, Ricardo Magan, Richard English, Simon Ticehurst, Steve Price Thomas, Tim Holmes, Tricia Parker, Trini Leung, Xavier Palau.

The paper is part of the Oxfam 'Influencing for Poverty Reduction and Social Justice' research series by the Oxfam Research Network.

For more information, or to comment on this paper, email Ruth Mayne at rmayne1@oxfam.org.uk

(c) Oxfam International January 2019

This publication is copyright but the text may be used free of charge for the purposes of advocacy, campaigning, education, and research, provided that the source is acknowledged in full. The copyright holder requests that all such use be registered with them for impact assessment purposes. For copying in any other circumstances, or for re-use in other publications, or for translation or adaptation, permission must be secured and a fee may be charged. E-mail policyandpractice@oxfam.org.uk.

The information in this publication is correct at the time of going to press.

Published by Oxfam GB for Oxfam International under ISBN 978-1-78748-395-8 in January 2019. DOI: $10.21201 / 2019.3958$

Oxfam GB, Oxfam House, John Smith Drive, Cowley, Oxford, OX4 2JY, UK.

\section{OXFAM}

Oxfam is an international confederation of 19 organizations networked together in more than 90 countries, as part of a global movement for change, to build a future free from the injustice of poverty. Please write to any of the agencies for further information, or visit www.oxfam.org.

Oxfam America (www.oxfamamerica.org)

Oxfam Australia (www.oxfam.org.au)

Oxfam-in-Belgium (www.oxfamsol.be)

Oxfam Brasil (www.oxfam.org.br)

Oxfam Canada (www.oxfam.ca)

Oxfam France (www.oxfamfrance.org)

Oxfam Germany (www.oxfam.de)

Oxfam GB (www.oxfam.org.uk)

Oxfam Hong Kong (www.oxfam.org.hk)

Oxfam IBIS (Denmark) (www.oxfamibis.dk)
Oxfam India (www.oxfamindia.org)

Oxfam Intermón (Spain) (www.oxfamintermon.org)

Oxfam Ireland (www.oxfamireland.org)

Oxfam Italy (www.oxfamitalia.org)

Oxfam Mexico (www.oxfammexico.org)

Oxfam New Zealand (www.oxfam.org.nz)

Oxfam Novib (Netherlands) (www.oxfamnovib.nl)

Oxfam Québec (www.oxfam.qc.ca)

Oxfam South Africa (www.oxfam.org.za)

Observer: KEDV (Oxfam Turkey) 